\title{
Species turnover and invasion of dominant freshwater invertebrates alter biodiversity-ecosystem-function relationship
}

\author{
Chelsea J. Little (iD) 1,2,3 and Florian Altermatt (iD 1,2 \\ ${ }^{1}$ Department of Aquatic Ecology, Eawag: Swiss Federal Institute of Aquatic Science and Technology, \\ Überlandstrasse 133, 8600 Dübendorf, Switzerland \\ ${ }^{2}$ Department of Evolutionary Biology and Environmental Studies, University of Zürich, Winterthurerstrasse 190, 8057 Zürich, Switzerland
}

\begin{abstract}
Freshwater ecosystems rely on allochthonous resources. Integration of these subsidies depends on diversity of both terrestrial resources and aquatic shredder and decomposer communities, but the diversity effects on leaf litter breakdown and decomposition are less clear in aquatic than terrestrial ecosystems. We need a better understanding of this relationship because aquatic communities are rapidly changing with species invasions and anthropogenic impacts. Here, we experimentally disentangled the effects of leaf and shredder richness on leaf litter breakdown by macroinvertebrates in mesocosm experiments using three species of amphipods, a dominant guild of crustaceans in European freshwater ecosystems. Increased leaf richness led to lower-than-predicted leaf consumption by native shredders, with mixed evidence of resource-switching or prioritization of preferred food items within a leaf mix. Higher shredder species richness never promoted leaf consumption rates compared to predictions from relevant single-species experiments, and instead sometimes substantially decreased leaf consumption. We then conducted a meta-analysis of leaf litter consumption rates by seven widely distributed amphipod species (the three used in the experiments and four additional species). As expected based on our own experiments, nonnative amphipod species generally had lower biomassadjusted leaf litter consumption rates, although their larger body size led to higher per-individual leaf consumption rates. Contamination of the water by metals, pesticides, and other chemicals additionally significantly decreased leaf litter consumption by multiple native and nonnative species compared to unpolluted systems. While the meta-analysis suggested that litter consumption, and thus breakdown, would decline if native shredders are replaced by nonnative heterospecifics, complete species replacement is not the only outcome following immigration in a meta-community context. Our experiments suggest that breakdown rates could remain reasonably high where native species coexist with nonnative arrivals. Experiments that neglect the ecological realism of species coexistence will necessarily mischaracterize effects on ecosystem functioning.
\end{abstract}

Key words: amphipod; decomposition; Dikerogammarus; Gammarus; keystone taxa; leaf litter; meta-analysis; nonnative species; shredder; species interactions.

\section{INTRODUCTION}

Despite the importance of biological diversity for ecosystem functions and services, our understanding of the relationship between biodiversity and ecosystem functioning remains partly unresolved, particularly at higher trophic levels (Loreau et al. 2001, Hooper et al. 2005, Mitchell et al. 2013, Brose and Hillebrand 2016). Biodiversity effects on ecosystem functioning may be non-linear and context dependent (Balvanera et al. 2006, Thébault and Loreau 2006, Thompson et al. 2016b). In terrestrial ecosystems, species richness is generally positively associated with higher productivity (Tilman et al. 2014), while diversity of consumers and detritus can promote faster decomposition (Hättenschwiler et al. 2005, Handa et al. 2014). Litter diversity can promote leaf litter breakdown and decomposition in freshwater systems (Cardinale et al. 2011), yet in terms of decomposers, the diversity-decomposition correlation seems less straightforward than in terrestrial ecosystems (Santschi et al. 2018). Both across terrestrial and aquatic ecosystems

Manuscript received 21 November 2017; revised 26 January 2018; accepted 6 February 2018. Corresponding Editor: Aimée T. Classen.

${ }^{3}$ E-mail: chelsea.jean.little@gmail.com
(Gessner et al. 2010) and in aquatic ecosystems more specifically (Creed et al. 2009), the presence of dominant species and strong competition between such species can reverse the sign of the diversity effect. This makes the identity and richness of dominant species in a community extremely important when considering decomposition rates.

Decomposition is of particular relevance in freshwater ecosystems because detrital inputs from terrestrial ecosystems support aquatic productivity, particularly in forested headwater streams (Wallace et al. 1997, Collins et al. 2016). In most fresh water, detritus is initially consumed by a dominant guild of invertebrates referred to as "shredders." Shredders provide a key service by producing particulate organic material that can be used by other functional groups of smaller organisms, and are a nutritional resource for larger consumers (Wallace and Webster 1996). In large parts of the northern hemisphere, amphipods (Crustacea: Amphipoda) are among the most dominant taxa of shredders. They are moderately diverse (Väinölä et al. 2007) but can dominate in biomass, especially in headwater streams (Nery and Schmera 2015). Amphipods have strong effects on ecosystem functioning and trophic structure (Dangles and Malmqvist 2004, Woodward et al. 2008). In fact, amphipods are responsible for European streams in particular having a 
larger share of decomposition performed by macroinvertebrates compared to aquatic ecosystems in other biomes worldwide, such that if these species are lost, decomposition declines dramatically (Handa et al. 2014).

Freshwater communities have been globally affected by the arrival of nonnative species in the last several decades (Ricciardi and MacIsaac 2000, Strayer 2010). Nonnative species have many negative effects, including impacts on community structure and food webs (Woodward and Hildrew 2001, MacDougall and Turkington 2005, Leuven et al. 2009). It is particularly essential to understand the effect of nonnative species on processes that link different trophic levels and affect basal resources (Capps and Flecker 2015); detritus breakdown is one such process (Webster and Benfield 1986). In some freshwater ecosystems, nonnative amphipods now make up more than one-half of all amphipod species and up to $95 \%$ of all amphipod (or even total) invertebrate biomass (Van den Brink et al. 1991). Given the essential role of amphipods in the resource pathways of freshwater communities, such community shifts due to invasion are likely to have ecosystem-level consequences.

In addition to community turn-over due to nonnative species, global changes and especially anthropogenic degradation of streams is a further confounding factor when considering the effect of nonnative species on ecosystem functioning. Nonnative species frequently invade patches that have been degraded (MacDougall and Turkington 2005, Früh et al. 2012), and this habitat modification may additionally influence the outcome of biotic interactions between native and nonnative species (Didham et al. 2007). These anthropogenic impacts alter the rates at which ecosystem functions like decomposition are performed by native species, even absent an invasion: for example nutrient runoff increases decomposition in streams (Ferreira et al. 2015), while acidity (Petrin et al. 2008) and heavy metals (Ferreira et al. 2016) decrease decomposition. Thus it is important to account for environmental conditions when assessing the contribution of nonnative species to ecosystem functioning, or considering whether a function such as decomposition may decline even if native communities are maintained.

Up to now, effects of nonnative decomposers on ecosystem processes have primarily been studied by comparing leaf breakdown rates in single-species monocultures of native vs. nonnative decomposer species (Jourdan et al. 2016), and also using single types of leaf resources (Piscart et al. 2011) even though litter input to streams is rarely limited to one tree species. Such tests lack the biological realism of a community context, and subsequent predictions of ecosystem function may have limited accuracy. Furthermore, most studies have been rather case-specific, and a synthetic integration and generalization of effects has been generally lacking. Thus, more realistically, the impact of a nonnative species depends not only on its functional efficiency in isolation, but also on whether native and nonnative species continue to coexist after an invasion (as with weak compared to strong invaders in plant communities, Ortega and Pearson 2005). While the diversity of native communities has been examined in relation to invasibility (Stachowicz et al. 1999, Shea and Chesson 2002, Alofs and Jackson 2014), the maintenance of diversity after arrival and establishment of nonnative species (Melbourne et al. 2007) may be of particular importance to ecosystem functioning. Thus we are lacking a consistent understanding of the generality, direction and magnitude of nonnative decomposer species' effects on freshwater ecosystems.

We performed laboratory experiments to test effects of decomposer and detritus species richness on leaf litter consumption, using three dominant amphipod species with different evolutionary and colonization histories and six leaf litter species as our study system. This experimental approach allows us to estimate the effects on (1) litter breakdown in a more realistic context where a terrestrial ecosystem provides diverse litter inputs to streams and (2) detrital breakdown rates when arriving nonnative species could join rather than replace the community of native amphipods. We then combined these laboratory experiments with an extensive meta-analysis to compare leaf litter consumption rates of native and nonnative amphipod species across geographical areas and detrital resource types. Combining data from diverse locations allows us to move beyond individual case studies to quantitatively address whether invaders can functionally replace native shredders. Specifically, we hypothesized that (1) all amphipod species would have higher consumption rates of nutrient-rich compared to nutrientpoor leaf types; (2) native amphipod species would have higher biomass-adjusted leaf consumption rates of leaves, compared to nonnative species, which may encounter different types of leaf resources in their native ranges; (3) multispecies mixtures of amphipods would have lower leaf consumption rates than that of a one-species population of the species with the highest consumption rate and also likely lower than an additively calculated expected consumption rate based on the rates of individual species in a mixture, due to interference competition; and leaf consumption would be higher in diverse leaf mixtures than would be expected from additively calculated consumption rates based on the component leaf types in the mixture, due to preferential feeding on higher-quality leaf types.

Because leaf breakdown is affected by environmental conditions, the effect of diversity on amphipod consumption of leaf litter must be understood in the context of these environmental conditions. Any predictions of the effect of an invasive species, for example, should take into account possible interspecific differences in thermal performance or suitability to local conditions. Thus, in our meta-analysis we examined common factors that may alter leaf consumption rates. We specifically hypothesized that (5) leaf consumption rates would be higher at warmer temperatures due to metabolic demands and that (6) leaf consumption rates would be lower in stressful environments, specifically when exposed to contaminants.

\section{Methods}

\section{Experiments}

Experimental study organisms. - We conducted experiments to measure leaf litter consumption by amphipod species in Central Europe, manipulating richness of both leaf litter (Experiment I) and amphipods (Experiment II). Three amphipod species were used in our experiments: the most common native amphipod species, Gammarus fossarum; one 
nonnative species that arrived in Central Europe around 1850 and has since been naturalized, Gammarus roeselii; and the most dominant invasive species, Dikerogammarus villosus, which arrived in the 1990s and was initially reported to be more predatory than other species (MacNeil and Platvoet 2005). These are three of the four most abundant amphipod species in northeastern Switzerland where the experiments were conducted (Altermatt et al. 2014). Although they are highly omnivorous, amphipods can perform the bulk of shredding activity in freshwater streams, particularly in central Europe (Piscart et al. 2009), and play a key role in their communities due to their high densities year-round in streams and some of their functional traits (Dangles and Malmqvist 2004). Functional traits of these species are summarized in Table 1.

For leaf litter, naturally senescent leaves from six common riparian tree species (Acer pseudoplatanus, Alnus glutinosa, Fagus sylvatica, Populus nigra, Quercus robur, and Salix caprea) were collected in November 2014 around Zürich, Switzerland and subsequently air-dried. These are among the most common tree species in deciduous forests in Switzerland, which are strongly beech dominated and where spruce, an economically important species nationwide, is no longer being planted as widely (Rigling and Schaffer 2015). A subset of leaves was analyzed for carbon, nitrogen, and phosphorus content (phosphorus, San++ automated wet chemistry analyzer, Skalar Analytical B.V., Breda, The Netherlands; nitrogen and carbon, Flash 2000 Elemental Analyzer coupled with Delta V Advantage IRMS, both manufactured by ThermoFisher Scientific, Bremen, Germany). The leaves used in the experiments represented a range of litter quality based on nutrient levels (Fig. 1).

Experiment I: Effects of leaf community richness. - In February 2015, leaves of all tree species were conditioned in large tubs in a 1:4 mix of local river water (Chriesbach, Dübendorf: $47^{\circ} 24^{\prime} 16^{\prime \prime} \mathrm{N} 8^{\circ} 36^{\prime} 33^{\prime \prime}$ E) to tap water in order to leach easily soluble secondary compounds and to allow colonization by a common microbial community. All conditioning and experiments took place with water at $18^{\circ} \mathrm{C}$. After 10

TABLE 1. Selected functional traits of amphipod species used in experiments and meta-analysis.

\begin{tabular}{|c|c|c|c|c|c|c|c|c|}
\hline & \multicolumn{3}{|c|}{ In our experiments } & \multicolumn{5}{|c|}{ In meta-analysis } \\
\hline & G. fossarum & G. roeselii & D. villosus & E. berilloni & $\begin{array}{l}\text { E. meridion- } \\
\text { alis }\end{array}$ & G. pulex & G. tigrinus & $\begin{array}{c}\text { G. pseudolim- } \\
\text { naeus }\end{array}$ \\
\hline $\begin{array}{l}\text { Feeding, } \\
\text { shredding }\end{array}$ & $0.7(1,2)$ & $0.5(1,2)$ & $0.2(1,2)$ & $0.5(1,2)$ & & $0.6(1,2)$ & $0.7(1,2)$ & \\
\hline $\begin{array}{l}\text { Feeding, } \\
\text { predator }\end{array}$ & $0(1,2)$ & $0.1(1,2)$ & $0.3(1,2)$ & $0(1,2)$ & & $0.1(1,2)$ & $0(1,2)$ & \\
\hline $\begin{array}{l}\text { Tachet } \\
\text { temperature } \\
\text { zone }\end{array}$ & $\begin{array}{l}\text { No specific } \\
\text { preference } \\
(1,3,4)\end{array}$ & $\begin{array}{l}\text { No specific } \\
\text { preference } \\
(1,3,4)\end{array}$ & $\begin{array}{l}\text { Preference for } \\
\text { warm (above } \\
\left.18^{\circ} \mathrm{C}\right)(1,3 \text {, } \\
4)\end{array}$ & $\begin{array}{l}\text { Preference for } \\
\text { warm (above } \\
\left.18^{\circ} \mathrm{C}\right)(1,3 \text {, } \\
4)\end{array}$ & $\begin{array}{l}\text { Preference for } \\
\text { warm (above } \\
\left.18^{\circ} \mathrm{C}\right)(1,3 \text {, } \\
4)\end{array}$ & $\begin{array}{l}\text { No specific } \\
\text { preference } \\
(1,3,4)\end{array}$ & $\begin{array}{l}\text { No specific } \\
\text { preference } \\
(1,3,4)\end{array}$ & \\
\hline $\begin{array}{l}\text { Other } \\
\text { temperature } \\
\text { information }\end{array}$ & $\begin{array}{l}11.8^{\circ} \mathrm{C} \text { for } \\
\text { reproduction } \\
(5)\end{array}$ & $\begin{array}{l}14^{\circ} \mathrm{C} \text { for } \\
\text { reproduction } \\
\text { (5) }\end{array}$ & $\begin{array}{l}\text { better cold ( } 5 \\
\left.-10^{\circ} \mathrm{C}\right) \\
\text { compared to } \\
\text { G. pulex }(6)\end{array}$ & & & $\begin{array}{l}\text { cold (7); } \\
\text { growth } \\
\text { optima } 15 \\
-21^{\circ} \mathrm{C} \\
(25)\end{array}$ & cold (7) & $\begin{array}{l}\text { thermal } \\
\text { optimum } 24 \\
-26^{\circ} \mathrm{C}(22)\end{array}$ \\
\hline $\begin{array}{l}\text { Stream } \\
\text { velocity } \\
\text { preference }\end{array}$ & $\begin{array}{l}\text { moderate to } \\
\text { high current } \\
(1,8)\end{array}$ & $\begin{array}{l}\text { slow streams, } \\
\text { standing } \\
\text { waters }(1,8)\end{array}$ & & $\begin{array}{l}\text { slow streams, } \\
\text { standing } \\
\text { waters }(1,8)\end{array}$ & & $\begin{array}{l}\text { moderate } \\
\text { to high } \\
\text { current } \\
(1,8)\end{array}$ & $\begin{array}{l}\text { slow } \\
\text { streams, } \\
\text { standing } \\
\text { waters } \\
(1,8)\end{array}$ & $\begin{array}{l}\text { avoids strong } \\
\text { currents } \\
(23,24)\end{array}$ \\
\hline Lentic/lotic & lotic $(1,9,10)$ & $\begin{array}{c}\text { lentic/lotic } \\
(1,9,10)\end{array}$ & $\begin{array}{l}\text { less lentic } \\
\text { than others } \\
\text { (11) }\end{array}$ & $\begin{array}{l}\text { lentic/lotic (1, } \\
9,10)\end{array}$ & lotic (12) & $\begin{array}{c}\text { lentic/lotic } \\
(1,9,10)\end{array}$ & $\begin{array}{c}\text { lentic/lotic } \\
(1,9,10)\end{array}$ & \\
\hline $\begin{array}{l}\text { Adult body } \\
\text { length, mm }\end{array}$ & $\begin{array}{l}\text { largest males } \\
14(13)\end{array}$ & $\begin{array}{l}\text { mean } 11.2 \\
\text { (male), } 9.2 \\
\text { (female) }(14)\end{array}$ & $\begin{array}{l}\text { mean } 11.4 \\
\text { (male), } 9.6 \\
\text { (female) }(15)\end{array}$ & $\begin{array}{l}\text { largest males } \\
20, \text { largest } \\
\text { females } 16 \\
(16)\end{array}$ & $\begin{array}{l}\text { largest males } \\
16(16)\end{array}$ & $\begin{array}{l}\text { mean } \\
\text { female } \\
\text { length } 8.9 \\
\text { (7) }\end{array}$ & $\begin{array}{l}\text { mean } \\
\text { female } \\
\text { length or } \\
10 \mathrm{~mm} \text {, } \\
6.5(7)\end{array}$ & $\begin{array}{l}\text { reproducing } \\
\text { females } 10- \\
13(23) ; \\
\text { overall, } \\
\text { adults } 7-16 \\
(24)\end{array}$ \\
\hline Life span & $>1$ yr (17) & $>1 \mathrm{yr}(17)$ & $\begin{array}{l}6-17 \text { months } \\
\text { (18) }\end{array}$ & & & $\begin{array}{l}15 \text { months } \\
\text { (7) }\end{array}$ & $\begin{array}{l}{ }^{6-} \\
15 \text { months } \\
\text { (7) }\end{array}$ & $1 \mathrm{yr}(24)$ \\
\hline $\begin{array}{l}\text { Eggs per } \\
\text { clutch }\end{array}$ & $\begin{array}{l}14.9(19), 9.6 \\
(20)\end{array}$ & 31.9 (19) & $\begin{array}{r}42.74(18) ; 43 \\
(19) ; 49(21)\end{array}$ & $31(21)$ & & $16(7)$ & $\begin{array}{l}28.7,30.7 \\
(7)\end{array}$ & $20-60(23)$ \\
\hline
\end{tabular}

Notes: Numbers in parentheses refer to sources, listed below. For feeding, number shows proportion of the species' overall feeding activity belonging to that function. Genera are Gammarus, Dikerogammarus, and Echinogammarus.

Sources: 1, Schmidt-Kloiber and Hering (2015); 2, Eder et al. (1995); 3, Working Group Aquatic Ecology (University Duisburg Essen) (2017); 4, Tachet et al. (2000); 5, Pöckl and Humpesch (1990); 6, Maazouzi et al. (2011); 7, Sainte-Marie (1991); 8, Schmedtje and Colling (1996); 9, Banning (1990); 10, Banning (1998); 11, Sidagyte et al. (2017); 12, Macedo-Sousa et al. (2007); 13, Goedmakers (1972); 14, Paganelli et al. (2016); 15, Devin et al. (2004); 16, Pinkster (1973), 17, Pöckl et al. (2003); 18, Pöckl (2009); 19, Pöckl (2007); 20, Beracko et al. (2012); 21, Kley and Maier (2006); 22, Galic and Forbes (2017); 23, Marchant and Hynes (1981); 24, Waters and Hokenstrom (1980); 25, Sutcliffe et al. (1981). 
a

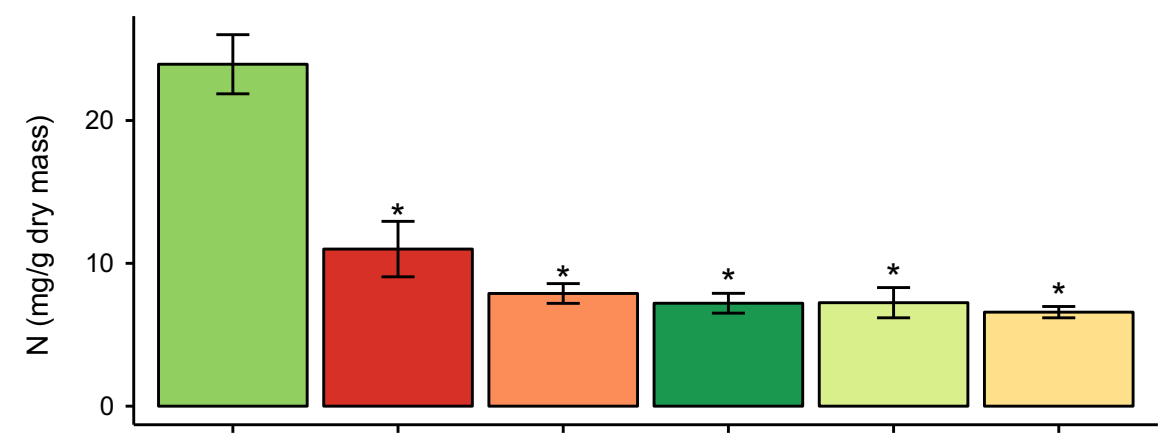

b
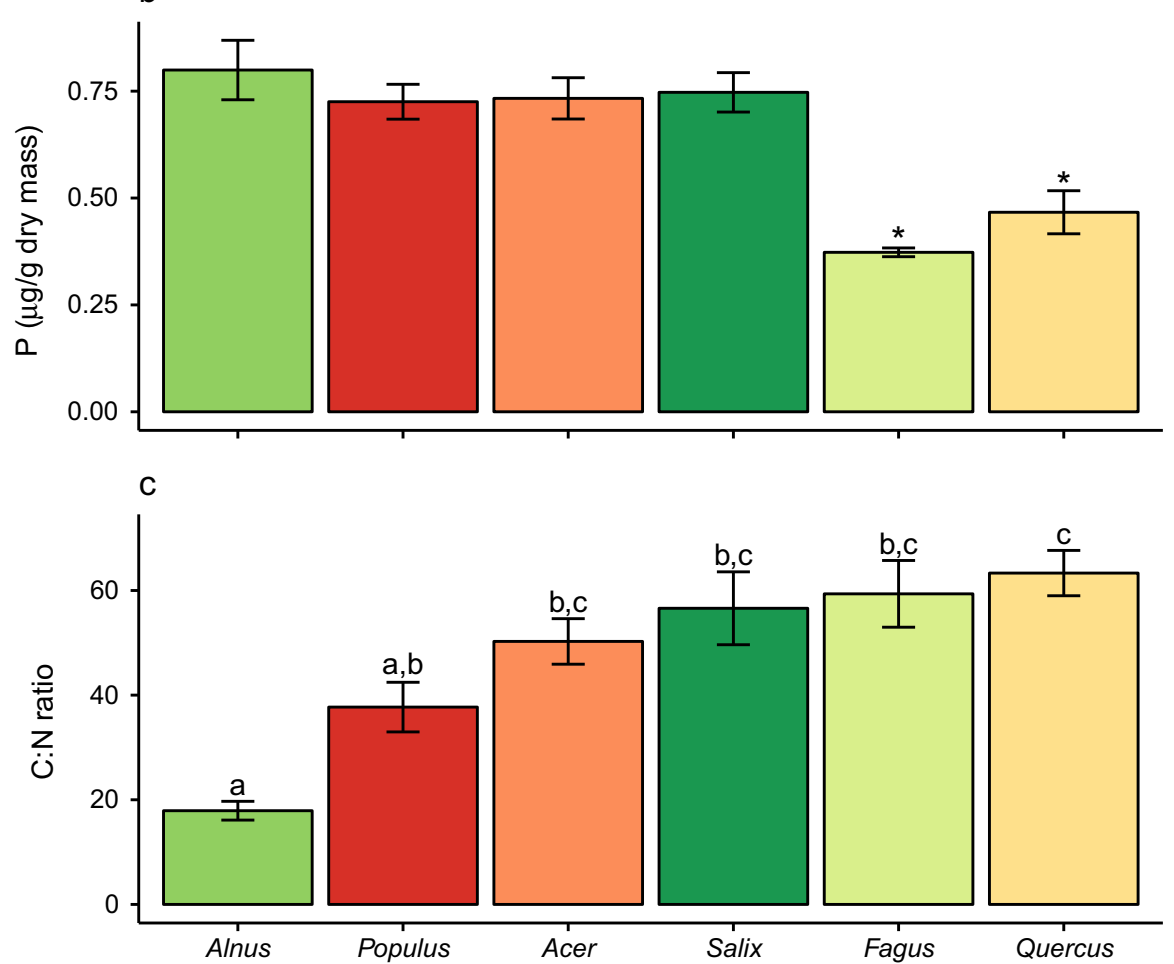

FIG. 1. Content of (a) nitrogen and (b) phosphorus and (c) resulting C:N ratios in samples of leaves from six species (Alnus glutinosa, Populus nigra, Acer pseudoplatanus, Salix caprea, Fagus sylvatica, and Quercus robur) used in Experiment I and Experiment II. Error bars show standard error. In panels a and $b$, asterisks indicate species with nutrient contents significantly different from the most nutrient-rich resource, alder leaves, and in panel c, bars with different letters indicate significant differences between C:N ratios (Tukey's HSD test, $P<0.05)$.

days, leaves were removed from the conditioning containers and photographed to measure leaf area using ImageJ (National Institutes of Health, Bethesda, Maryland, USA). A subset of 20-30 leaves per type were photographed, dried at $60^{\circ} \mathrm{C}$, and weighed to develop allometric area-to-mass relationships for each species (Table 2). Leaves were added to 3 - $\mathrm{L}$ mesocosms so that each mesocosm would contain roughly $1.2 \mathrm{~g}$ dry biomass of leaf litter. Mesocosms were placed on racks where water (primarily tap water, as the entire system comprised $\sim 1,250 \mathrm{~L}$, but mixed with some stream water as well) circulated through them continuously. Twelve leaf treatment types were implemented: monocultures of Acer, Alnus, Fagus, Quercus, Populus, and Salix; a six-species leaf mixture; and pairwise mixtures of AlnusFagus, Alnus-Acer, Alnus-Quercus, Alnus-Populus, and Alnus-Salix mixes. This was based on the high nutrient content of Alnus (Fig. 1), which may make it a preferred food source and also maximize dissimilarity between species in a mixture, which can be important for decomposition rates (Lecerf et al. 2011).

Gammarus fossarum were collected in kick nets from Chämmeterbach (Dübendorf, Switzerland: 47²3'28" N $8^{\circ} 36^{\prime} 00^{\prime \prime}$ E), transported back to the laboratory, and placed overnight in larger tubs of stream water and ad libitum Alnus leaves. G. fossarum was chosen for this experiment because it is by far the most common native amphipod species in local headwater streams, as well as throughout large regions of central Europe. The next day, five individuals of $G$. fossarum were added to each of eight replicate mesocosms per treatment type. Four no-amphipod control mesocosms were also established for each monoculture type and for the six-species mix to measure and control for microbial and fungal 
TABLE 2. Conversions used to calculate leaf consumption rates from different studies into comparable units.

\begin{tabular}{|c|c|c|c|}
\hline Original units & New units & Conversion & Source \\
\hline $\mathrm{mm}^{2}$ leaf loss, alder & mg DM leaf loss, alder & $\left(\mathrm{mm}^{2}\right.$ area $\left.\times 0.0552\right)+10.89$ & This paper \\
\hline $\mathrm{mm}^{2}$ leaf loss, alder & mg DM leaf loss, alder & $\begin{array}{r}\mathrm{mm}^{2} \text { area } \times\left(0.035 \mathrm{~g} / 4.62 \mathrm{~cm}^{2}\right) \times \\
\left(1 \mathrm{~cm}^{2} / 100 \mathrm{~mm}^{2}\right) \times(1000 \mathrm{mg} / \mathrm{g})\end{array}$ & Boeker and Geist (2015) \\
\hline $\mathrm{mm}^{2}$ leaf loss, beech & mg DM leaf loss, beech & $\left(\mathrm{mm}^{2}\right.$ area $\left.\times 0.0194\right)+54.843$ & This paper \\
\hline $\mathrm{mm}^{2}$ leaf loss, maple & mg DM leaf loss, maple & $\left(\mathrm{mm}^{2}\right.$ area $\left.\times 0.0396\right)+1.8049$ & This paper \\
\hline $\mathrm{mm}^{2}$ leaf loss, oak & mg DM leaf loss, oak & $\left(\mathrm{mm}^{2}\right.$ area $\left.\times 0.0762\right)-16.341$ & This paper \\
\hline $\mathrm{mm}^{2}$ leaf loss, poplar & mg DM leaf loss, poplar & $\left(\mathrm{mm}^{2}\right.$ area $\left.\times 0.0907\right)-80.043$ & This paper \\
\hline $\mathrm{mm}^{2}$ leaf loss, willow & mg DM leaf loss, willow & $\left(\mathrm{mm}^{2}\right.$ area $\left.\times 0.0366\right)+113.34$ & This paper \\
\hline mg WM, all leaves & mg DM, all leaves & $\mathrm{mg} \mathrm{WM} \times 0.163$ & Jourdan et al. (2016) \\
\hline $\mathrm{mg} \mathrm{C}$, all leaves & mg DM, leaves & $\underset{\text { (intermittent reach) }}{\mathrm{mg} \mathrm{C} \times 0.514 \text { (permanent reach) } \text { or } \mathrm{mg} \mathrm{C} \times 0.5245}$ & Mas-Martí et al. (2015) \\
\hline mg AFDM, alder & mg DM, alder & $\mathrm{mg}$ AFDM/0.941 & This paper \\
\hline mg AFDM, beech & mg DM, beech & mg AFDM/0.943 & This paper \\
\hline mg AFDM, oak & mg DM, oak & mg AFDM/0.961 & This paper \\
\hline mg WM, amphipods & mg DM, amphipods & $\mathrm{mg} \mathrm{WM} \times 0.20$ & Ricciardi \& Bourget (1998) \\
\hline mg AFDM, amphipods & mg DM, amphipods & mg AFDM/0.729 & Ricciardi \& Bourget (1998) \\
\hline
\end{tabular}

Note: WM, wet mass; DM, dry mass; C, carbon; AFDM, ash-free dry mass.

decomposition in the laboratory setup. Based on previous work (Santschi et al. 2018) we knew that microbial decomposition in such a setting and time span was very low.

Due to some mortality associated with handling (Danger et al. 2013, Dehedin et al. 2013b), we replenished deceased amphipods in all replicates during the first week. After that, dead amphipods were not replaced, but merely counted and removed from each mesocosm after 14,21 , and $28 \mathrm{~d}$, at which point we counted all remaining amphipods in each mesocosm, preserved them in ethanol, dried them at $60^{\circ} \mathrm{C}$ to constant mass, and weighed them. We used the number of amphipods alive at each count over the course of the experiment to calculate a total number of "amphipod-days" accumulated in each mesocosm, and multiplied this by the average mass of an amphipod in that particular mesocosm to get a total biomass of amphipods over the course of the experiment. We also photographed all leaves, measured their area, and then converted area to mass loss using the allometric relationships developed above. Consumption rates were calculated as mg of dry mass lost per mg biomass of amphipod per day, were corrected by the average mass loss of that species in control mesocosms, which did not contain amphipods, and were calculated separately for each species in mixtures.

In all of our experiments, there were some mesocosms where no leaf litter was consumed. A small consumption rate below detectability is not uncommon, as amphipods can survive for at least two weeks under starvation conditions (Nyman et al. 2013). Thus, we considered low consumption rates to reflect low preferences. To determine whether the no-consumption mesocosms were distributed evenly between treatments, we always used a two-step hurdle model, with leaf consumption first modeled as a binary process $(0=$ no leaf material consumed, $n=51 ; 1=$ leaf material consumed, $n=116$ ) using a binomial GLM. Then, if there were no differences between treatments, the full data set of breakdown rates was considered in a second model; if there were differences in the distribution of no-consumption mesocosms by treatments, then the second model was made using only the data from mesocosms where some leaf consumption occurred. In Experiment I, consumption rates were square root transformed to correct for heteroscedasticity of data. Differences in consumption rates between monocultures were analyzed using linear models with leaf species as a fixed effect; all analyses were performed in $\mathrm{R}$ version 3.2.5 ( $\mathrm{R}$ Core Team 2016). Where species was a significant factor in explaining leaf consumption rates, pairwise Tukey's HSD tests were conducted using multcomp package version 1.4-1 (Hothorn et al. 2008).

Expected consumption rates of two- and six-species mixes, as well as the variance of these predictions, were calculated additively based on consumption rates of relevant monocultures. Briefly, average consumption rates of each of the component monocultures were averaged to determine an expected leaf consumption rate of a mixture, and a pooled variance from all the component monocultures was calculated to represent the expected variance of the mixture. These expected consumption rates were compared to the rates observed in the experiment using $t$ tests with the assumption of unequal variance. Next, consumption rates of individual species in monocultures, two-species mixes, and the six-species mix were compared using species identity and treatment (combination type) as fixed factors. This was first done separately for Alnus (which was present in seven different treatments) and then for the other five species together (which were each present in three different treatment types, classified as "alone," "with Alnus," and "six-species"). Pairwise comparisons between consumption rates in monocultures and mixes were assessed for each leaf type individually using the Tukey's HSD tests.

Experiment II: Effects of amphipod species richness.-For the second experiment, leaves of Alnus, Fagus, and Quercus were conditioned as in Experiment I and placed into mesocosms in monocultures at $18^{\circ} \mathrm{C}$. We collected individuals of D. villosus, G. fossarum, and $G$. roeselii from two different sites per species in the Swiss catchment area of lake Constance (from 47 $39^{\prime} 43^{\prime \prime} \mathrm{N} 8^{\circ} 58^{\prime} 17^{\prime \prime}$ E to $47^{\circ} 28^{\prime} 49^{\prime \prime} \mathrm{N}$ $9^{\circ} 33^{\prime} 57^{\prime \prime} \mathrm{E}$ ) in June 2015. Individuals were identified to species level in the field based on morphology and acclimated to laboratory conditions as in Experiment I. 
This experiment had two factors, amphipod community richness and leaf type. There were seven amphipod richness treatment types: three single-species treatments, all three pairwise combination treatments, and a three-species treatment. Each of these community structures can occur at sites in Eastern Switzerland (Altermatt et al. 2016). Each 2-L mesocosm type received a total of 12 amphipods, with equal numbers per species in the case of the two-species treatments (six individuals of each species) and three-species treatment (four individuals of each species). Thus, it is a substitutive design holding the number of consumers constant but changing the identity of the consumers between treatments, and examining the effects of interspecific competition without being able to simultaneously measure the effects of intraspecific competition. This equal density of individuals resulted in unequal biomass per mesocosm, since G. fossarum weighed on average $2.24 \mathrm{mg}$, G. roeselii $3.96 \mathrm{mg}$, and D. villosus $3.90 \mathrm{mg}$. These relative densities are within the range of observed densities in Swiss headwater streams where these species can co-occur (Altermatt et al. 2016, Little and Altermatt 2017). However, as in Experiment I, consumption rates were calculated per biomass of amphipods rather than per individual to account for these differences. Consumption rates were also adjusted by mass loss in no-amphipod controls in Experiment I, as experimental conditions were identical with regards to equipment and water temperature.

Each of these seven amphipod richness treatments was crossed with each of the three different leaf types. All treatment combinations were replicated eight times. We replenished handling-related deceased amphipods in all replicates after two days. Subsequent mortality was recorded and dead amphipods removed, but not replaced. The total number of live amphipods remaining was recorded three times per week. After 15 days, all amphipods were counted and removed from the mesocosms. To see whether mortality differed between the focal species or depending on treatment, survival of amphipods was analyzed using a linear model with species and amphipod richness treatment as interacting fixed effects. Leaves were analyzed for mass loss and amphipods were extracted, dried, and weighed as in Experiment I. Biomass of amphipods in mesocosms was calculated as for Experiment I, with survival of different species over the course of the experiment assumed to be proportional to total survival at the end of the experiment.

Consumption rates from Experiment II were analyzed using a two-step generalized linear model due to zero-inflation of the consumption data. A small consumption rate below detectability is not uncommon, as amphipods can survive for at least two weeks under starvation conditions (Nyman et al. 2013). Thus, we considered low consumption rates to reflect low preferences. For the analysis, leaf consumption was first modeled as a binary process $(0=$ no leaf material consumed, $n=51 ; 1=$ leaf material consumed, $n=116$ ) using a binomial GLM. Second, consumption in mesocosms where amphipods did consume leaf litter was analyzed using a gamma GLM. Leaf type and amphipod treatment were included as interacting fixed factors in an initial model and backwards stepwise selection using Akaike information criterion (AIC) scores was used to identify significant explanatory factors. When appropriate, differences between treatments were explored using Tukey's HSD testing.

\section{Meta-analysis}

In order to understand whether the results of our experiments were general across amphipod taxa, we conducted a systematic review of leaf consumption rates by freshwater amphipods. We initially searched for experiments that incorporated different levels of species richness (as in our own experiments), but found very few of such studies (MacNeil et al. 2011, Constable and Birkby 2016). Instead, we compiled measurements of leaf consumption by single native and nonnative amphipod species. We searched peerreviewed, English language literature available on Web of Science and Google Scholar in October 2016. Our inclusion criteria were as follows, with all points needing to be satisfied for inclusion in the meta-analysis; a study must:

1) Report leaf consumption rate(s) by a species in the Gammaridae family, an important group of shredders, which also contains the three focal species from our own experiments.

2) Measure the consumption rate on a single leaf type(s), but this could be any tree species.

3) Reported water type (tap water, reference stream water, stream water impacted by pollution, or stream water plus a contaminant or toxin).

4) Report experimental duration.

5) Report the number of amphipods in each experimental unit.

6) Contain consumption rates that were convertible (Table 2) into units of mg dry mass leaves (or transformable therein) consumed per amphipod individual per day, or mg dry mass leaves consumed per biomass of amphipod dry mass per day.

7) Report sample size (number of replicates) and some measure of variance that could be converted into standard deviation.

We limited our search for consumption rates in monocultures, leaving out consumption rates of mixed-leaf combinations, "food choice" experiments, or other experiments where more than one resource type was provided to amphipods, or consumption rates by mixed-amphipod populations.

For the search, we used combinations of the keywords "Gammarus," "Dikerogammarus," or "*gammar*" with "alder," "beech," "maple," "oak," "poplar," "willow," "elm," "Alnus," "Fagus," "Acer," "Quercus," "Populus," "Salix," or "consumption rate." We retained all papers found in Web of Science, as well as the first $\sim 20 \%$ of results from each Google Scholar search. The rest of Google Scholar results were screened by title and only retained if potentially appropriate for inclusion, as most results were obviously not relevant. Google Scholar is often used to include gray literature in systematic reviews (Haddaway et al. 2015), however, this route did not produce relevant gray literature in our case. We found in total 2,001 records fulfilling our search criteria across all searches in Web of Science and Google Scholar. Of these, we excluded 1,342 based on title alone; we discarded 372 more as duplicates. This process produced 287 studies to be screened by abstract and full text. Of those, 227 papers were discarded because they did not meet the inclusion criteria. A further 18 studies could not be extracted due to incomplete 
data or inappropriate units (for instance, consumption rate as a percent of initial leaf mass, but with no report of the initial leaf mass). This yielded 53 studies (Bird and Kaushik 1985, Bärlocher 1990, Sridhar and Bärlocher 1993, Friberg and Jacobsen 1994, Sridhar et al. 2001, Dangles and Chauvet 2003, Franken et al. 2005, Krauss et al. 2005, Schlief and Mutz 2006, Gergs and Rothhaupt 2008, Zubrod et al. 2010, 2015, 2017a, b, Aßmann et al. 2011, Bundschuh et al. 2011, 2013, 2017, Coulaud et al. 2011, Lagrue et al. 2011, Navel et al. 2011, Piscart et al. 2011, Reiss et al. 2011, Jabiol and Chauvet 2012, Danger et al. 2013, Dedourge-Geffard et al. 2013, Dehedin et al. 2013a, Foucreau et al. 2013a, b, 2016, Agatz and Brown 2014, Dray et al. 2014, Dunoyer et al. 2014, Gonçalves et al. 2014, Truhlar et al. 2014, Boeker and Geist 2015, MasMartí et al. 2015, Schmidlin et al. 2015a, b, c, Colas et al. 2016, Constable and Birkby 2016, Jourdan et al. 2016, Pesce et al. 2016, De Castro-Català et al. 2017, Galic and Forbes 2017, Kenna et al. 2017). Summary data of leaf consumption rates were extracted from the studies preferentially from text/tables, or where necessary from figures using ImageJ (National Institutes of Health) to extract means and variances. Finally, we added 30 measurements from the single-species treatments of our own experiments to our database. Consumption rates were used as the outcome of interest using the metafor package version 1.9-8 (Viechtbauer 2010).

Overall estimates of consumption rates were made using a random-effects model. For initial estimates of consumption rates, studies were included that implemented variable temperatures or were performed in-stream with natural temperature fluctuations.

Next, we used an additive mixed-effects model to assess how consumption rates were influenced by amphipod species (functional traits of amphipod species used in the meta-analysis are summarized in Table 1), leaf type, amphipod density, duration of experiment, water temperature, and water contamination. While the differences in leaf consumption rates for amphipod species and leaf types were our primary interest, differences in experimental conditions between different studies meant both that we needed to control for possible confounding factors, and that we had an opportunity to examine some factors' biological effects. In this analysis, only those studies using stable temperatures were included. Model selection was performed using AIC values and the glmulti package version 1.0.7 (Calcagno 2013). Across all 64 possible additive models, each explanatory variable was assessed for importance using the sum of the relative evidence weights from all the models where the variable appeared. Variables having a summed relative importance greater than a cutoff value of 0.8 were included in the final model.

In order to further determine the effect of these "important" variables, we planned to conduct separate, smaller meta-analyses of their effect size using only studies that manipulated the variable in question, holding all other variables equal. However, only for water contamination were there a sufficient number of studies manipulating the variable to consider this a meaningful exercise. To assess whether this variable biased the overall results, we also repeated the global meta-analysis using only samples with uncontaminated water and compared the result to that of the larger analysis.

\section{RESULTS}

Our experiments and subsequent meta-analysis found substantial and highly significant differences in leaf consumption rates based on amphipod identity, leaf identity, and community richness. Below, we initially address the effects of increasing species richness, and then consider patterns of leaf consumption across a wider number of native and nonnative amphipod species in the meta-analysis.

\section{Experimental single-species consumption rates}

In Experiment I, consumption rates by G. fossarum of monocultures depended on leaf type $\left(F_{5,41}=17.31\right.$, $P<0.001$, adjusted $R^{2}=0.64$; Fig. 2a). While there were some mesocosms where no leaves were consumed, this did not vary by leaf type (Tukey's HSD, all $P>0.3$ ). Alnus leaves in monocultures were consumed faster than all other leaf types except for Quercus (Tukey's HSD, $P=0.67$; for all other comparisons to Alnus, $P<0.05$ ). Acer had the lowest leaf consumption rate, significantly lower than in Quercus (Tukey's HSD, $P=0.02$ ) and just $13 \%$ of the rate of Alnus.

In Experiment II, no Quercus leaf litter was consumed by either G. fossarum or D. villosus (Fig. 2b). The prevalence of mesocosms where no leaf litter was consumed varied with both leaf litter type and amphipod species: G. roeselii consumed leaf litter in more mesocosms than D. villosus did (Tukey's HSD, $P=0.01$ ), but neither species was significantly different from G. fossarum (Tukey's HSD, both $P>0.20)$. There was no significant interaction between amphipod species and leaf type ( $\triangle \mathrm{AIC}$ between models with and without the interaction $=1.5$ ).

Among mesocosms where leaf litter was consumed, consumption rates varied among amphipod species and leaf types, with a significant interaction between the two $\left(F_{86,38}=14.11, P<0.001\right.$, adjusted $R^{2}=0.64$; Fig. 2 c). For Alnus, $G$. roeselii had a higher consumption rate than $G$. fossarum (Tukey's HSD, $P=0.03$ ), with $D$. villosus having an intermediate consumption rate between the other two species. For both $G$. roeselii and $D$. villosus, consumption rates of Alnus were significantly higher than those of the other two leaf types (Tukey's HSD, $P<0.05$ ). For $G$. fossarum, the consumption rates of Alnus and Fagus were not significantly different (Tukey's HSD, $P=0.09$ ), just as had been found in Experiment I (Fig. 2a).

\section{Effects of leaf richness on consumption rates}

Consumption rates in some leaf mixtures were higher than would be predicted based on rates in relevant single-species treatments, and in other mixtures were lower (Fig. 3a). For the six-species mix $\left(t_{14}=7.004, P<0.001\right)$, there was a significant decline in leaf consumption rate compared to the expectation calculated from monocultures. Within the mixtures, Alnus consumption rates varied significantly between different treatments $\left(F_{6,48}=8.518, \quad P<0.001\right.$, adjusted $R^{2}=0.46$ ). Of all the mixtures, the highest consumption rates of Alnus leaves came when they were combined with 

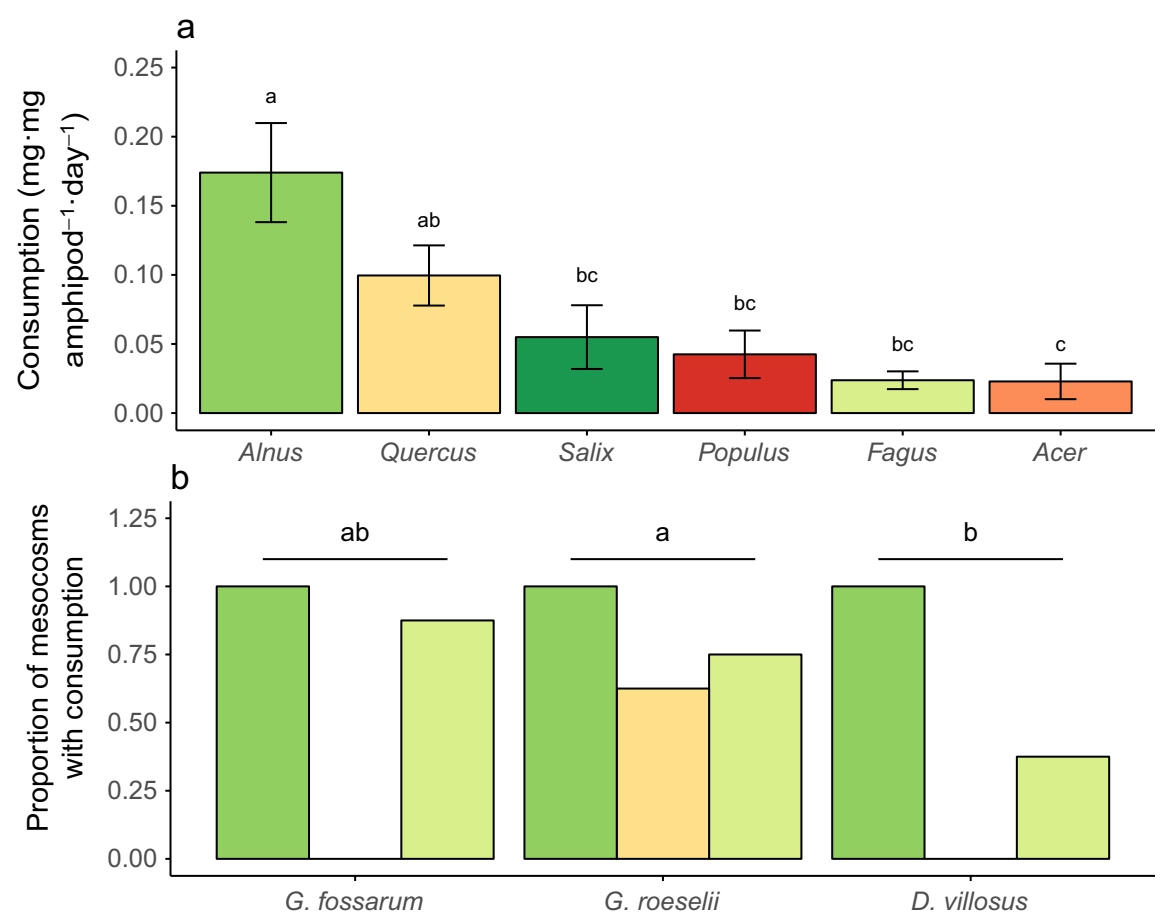

C

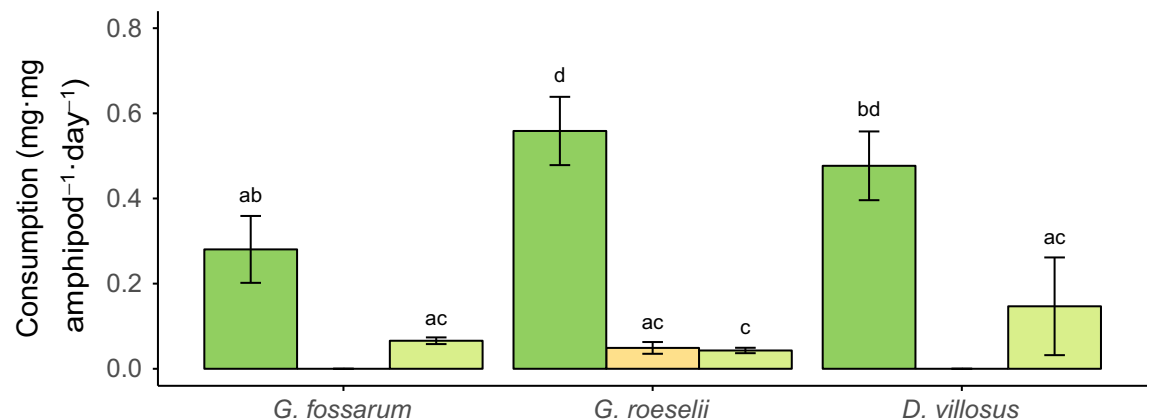

FIG. 2. (a) Consumption rates (mean \pm SE) of six common leaf types by Gammarus fossarum, the most common native amphipod of Central Europe (Experiment I). (b) The proportion of mesocosms where leaf litter was consumed in Experiment II for a smaller subset of three leaf types (bars colored as in panel a) by G. fossarum, the naturalized nonnative G. roeselii, and the recent invader Dikerogammarus villosus, and (c) consumption rates (mean $\pm \mathrm{SE}$ ) of the three most common leaf types in a the same experiment, in those mesocosms where leaf litter was consumed. Different letters indicate significant differences between consumption rates (Tukey's HSD test, $P<0.05$ ). In panel b, there was also a significant difference (Tukey's HSD test, $P=0.004$ ) between leaf consumption rates of Fagus and Alnus, but no significant interaction between leaf type and amphipod species.

Quercus $\left(0.15 \mathrm{mg} \cdot \mathrm{mg}\right.$ amphipod $\left.{ }^{-1} \cdot \mathrm{d}^{-1}\right)$, whereas the consumption rate when placed in the six-species mix was zero (Fig. 3b). Consumption rates of Alnus in the six-species mix as well as the Populus and Salix mixes were lower than when in monocultures (simultaneous linear tests, $P<0.015$; $P>0.05$ for all other mixes). For the other five leaf types, there was a significant interaction between focal species and the treatment/mixture the species was included in $\left(F_{14,104}=11.39, P<0.001\right.$, adjusted $\left.R^{2}=0.55\right)$. For all species except maple, consumption rates in mixtures were significantly lower than in monocultures (Fig. 3c; simultaneous linear tests, all $P<0.01$; maple, both $P>0.3$ ).

\section{Effects of amphipod richness on leaf consumption rates}

Survival of amphipods varied with species and richness treatment $\left(F_{20,146}=10.32, P<0.0001\right)$. G. fossarum and
G. roeselii had $\sim 50 \%$ and $\sim 20-25 \%$ lower survival, respectively, in mesocosms also containing D. villosus than when kept in single-species mesocosms or alongside one another (Fig. 4). Survival of D. villosus did not vary with amphipod combination but was slightly lower across all treatments than that of either G. fossarum or G. roeselii when kept in monocultures. Consumption rates in mesocosms with mixed amphipod species were most often lower than expected based on rates in single-species mesocosms, though only significantly so for the $G$. fossarum-G. roeselii combination feeding on Quercus $\left(t_{14}=-2.50, P=0.02\right)$, the $G$. roeselii-D. villosus combination feeding on Quercus $\left(t_{14}=-2.37, P=0.03\right)$, and the three-species mixture feeding on Fagus $\left(t_{14}=-2.17, P=0.04\right)$. The feeding rates of all mixed-species mesocosms on Quercus was near zero (Fig. 5). 

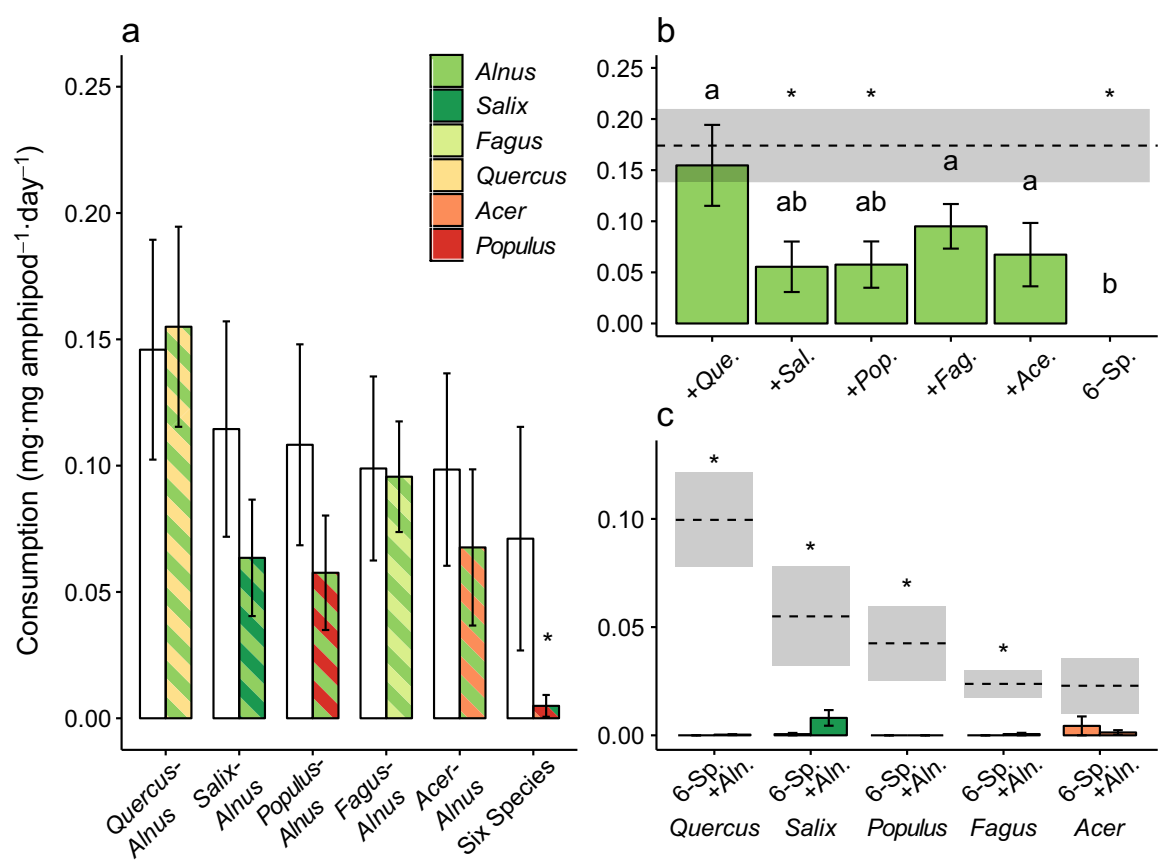

FIG. 3. Consumption rates by G. fossarum in mixed-leaf mesocosms (a, colored bars) were always lower than predicted (a, white bars) based on consumption rates in respective monocultures (shown in Fig. 1a). Within leaf mixtures, consumption rates of Alnus leaves (b) varied depending on biotic context and consumption rate in some mixtures differed from that in monocultures, represented by the dashed line and gray box (mean $\pm \mathrm{SE}$ ). Consumption rates of other species were also typically lower in mixtures (c) compared to in monocultures (again shown with dashed line and gray box), though not always significantly so. Bars with different letters (b) or asterisks (c) indicate significant differences between consumption rates (Tukey's HSD test, $P<0.05$ ). Abbreviations are Aln., Alnus; Que., Quercus; Sal., Salix; Pop., Populus; Fag., Fagus; Ace., Acer; and 6-Sp., six species.

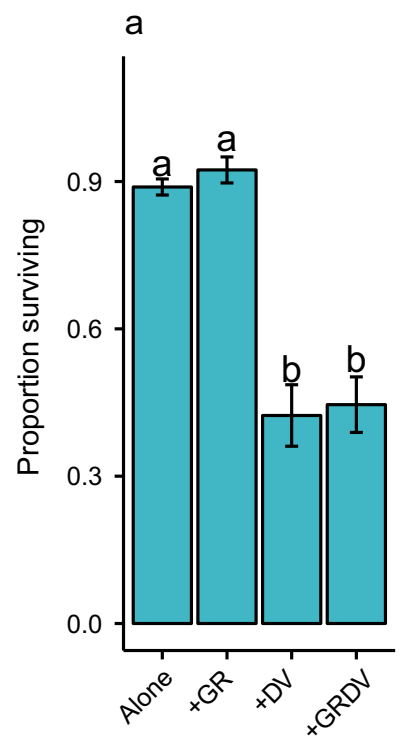

GF Treatment

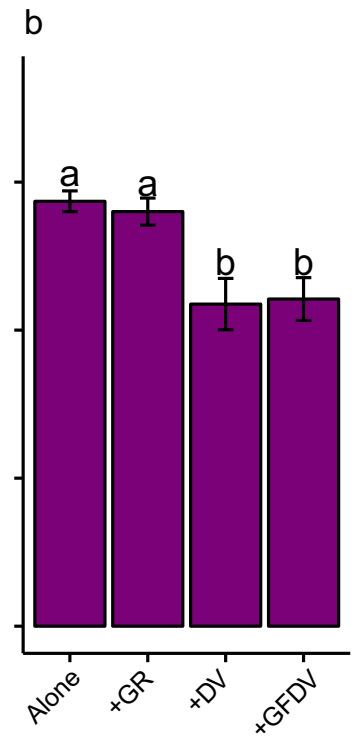

GR Treatment

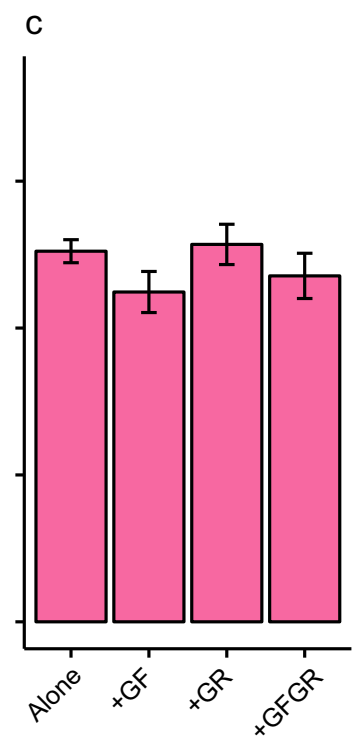

DV Treatment

FIG. 4. Proportion of (a) Gammarus fossarum (GF), (b) Gammarus roeselii (GR), and (c) Dikerogammarus villosus (DV) surviving when in isolation ("alone") and when placed mesocosms with one or more other species. Error bars show SE. Bars with different letters indicate significant differences between survival rates (Tukey's HSD test, $P<0.05$ ).

\section{Meta-analysis of single-species consumption rates}

Across species and study conditions in all 497 total data points, consumption rates of leaf litter averaged $1.030 \mathrm{mg}$ amphipod/d $(95 \%$ confidence interval $0.873-$
$1.187, n=172)$ or $0.175 \mathrm{mg} \cdot \mathrm{mg}$ amphipod ${ }^{-1} \cdot \mathrm{d}^{-1} \quad(95 \%$ confidence interval $0.155-0.195, n=387$ ). This data set comprised five native species (G. fossarum, Gammarus pulex, Gammarus pseudolimnaeus, Echinogammarus berilloni, and Echinogammarus meridionalis) and three 

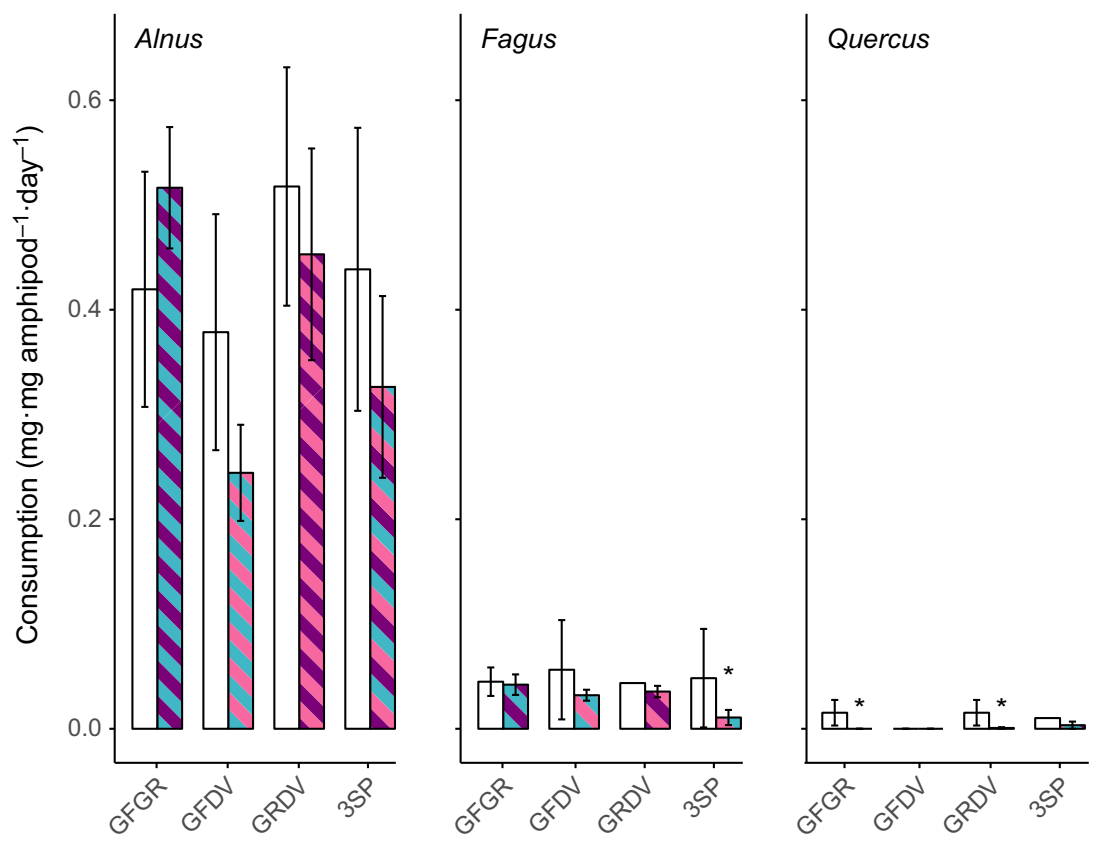

FIG. 5. Consumption rates (mean $\pm \mathrm{SE}$ ) in mixed-species amphipod mesocosms on Alnus, Fagus, and Quercus leaves, with colored bars showing observed values and white bars showing expected values calculated from consumption rates in relevant monocultures (shown in Fig. 1b). Asterisks show significant differences between observed and expected consumption rates (simultaneous $t$ tests, $P<0.05$ ). 3SP, all three species.

nonnative species (G. roeselii, Gammarus tigrinus, and D. villosus).

Model selection for body-mass-adjusted consumption rates measured at constant temperatures (358 data points) showed that amphipod species, leaf type, length of experiment, and water contamination were included in the best-fitting model (model weight $=0.38$ ). This model explained $45.58 \%$ of the heterogeneity in the data set, as did the second-best model $\left(\Delta \mathrm{AIC}_{\mathrm{c}}=0.01\right.$, model weight $\left.=0.38\right)$, which also included water temperature. No other models were within two $\mathrm{AIC}_{\mathrm{c}}$ units (the Akaike information criterion corrected for sample size) of these models. Multimodel inference showed that amphipod water temperature was relatively unimportant (importance $=0.50$, the lowest of any potential explanatory factors in the best two models, with all others having importance $>0.99$ ).

Because we were interested in determining leaf consumption rates in natural ecosystems and water contamination was shown to have a significant impact on leaf consumption rates, we decided to assess the impact of water contamination separately, and first repeat the general analysis with only measurement made with uncontaminated water $(n=280)$. For this subset of data, model selection showed that amphipod species, leaf type, length of experiment, water temperature, and amphipod density were included in the best-fitting model. There was one other models within two $\mathrm{AIC}_{\mathrm{c}}$ units, which did not include water temperature and carried $29.4 \%$ of the weight in the model set vs. $70 \%$ of the weight going to the best-fitting model. Indeed, model-averaged importance of water temperature was only 0.70 , whereas the importance of all the other factors was $>0.99$. And when the five factors tested separately using the Knapp-Hartung adjustment (Knapp and Hartung 2003), each factor explained a significant $(P<0.001)$ amount of variability except for temperature $(P=0.06)$. For ease of visual interpretation, the effects of each explanatory variable are presented separately.

Leaf consumption in non-contaminated water varied by amphipod species (Fig. 6a), with highest body-massadjusted consumption rates by the native $G$. pulex and nonnative $G$. roeselii, and the lowest by the nonnative $D$. villosus. However, data was not evenly distributed among amphipod species, with only $18.2 \%$ of the leaf consumption rates measurements made on the three nonnative species (D. villosus, G. tigrinus, and G. roeselii) compared to $81 \%$ of measurements on the five native species. Similarly, not all leaf types were studied for all amphipod species. For many amphipod species, nitrogen-rich Alnus leaves were the most efficiently consumed resource (Fig. 6b). This could partially bias the estimates of mean consumption rates by different amphipod species, in particular by G. roeselii as Alnus was their most highly consumed leaf type and comprised $78 \%$ of the measurements of leaf consumption rate for this species, whereas only $19-38 \%$ of measurements were made on Alnus for other species, and G. pseudolimnaeus was never measured consuming Alnus, perhaps causing its overall low consumption rate in the meta-analysis. Consumption rates also varied with experimental or abiotic conditions. Increasing temperature was included in some of the best models but not considered important (Fig. 6c), while experimental duration (Fig. 6d) and density of amphipods (Fig. 6e) both had negative effects on leaf consumption rates. However, examination of these moderators showed that not all experimental (or natural) conditions are equally well represented in the data set, with more studies using short periods of time and single-amphipod mesocosms, introducing bias into predictions of community-level consumption rates. 

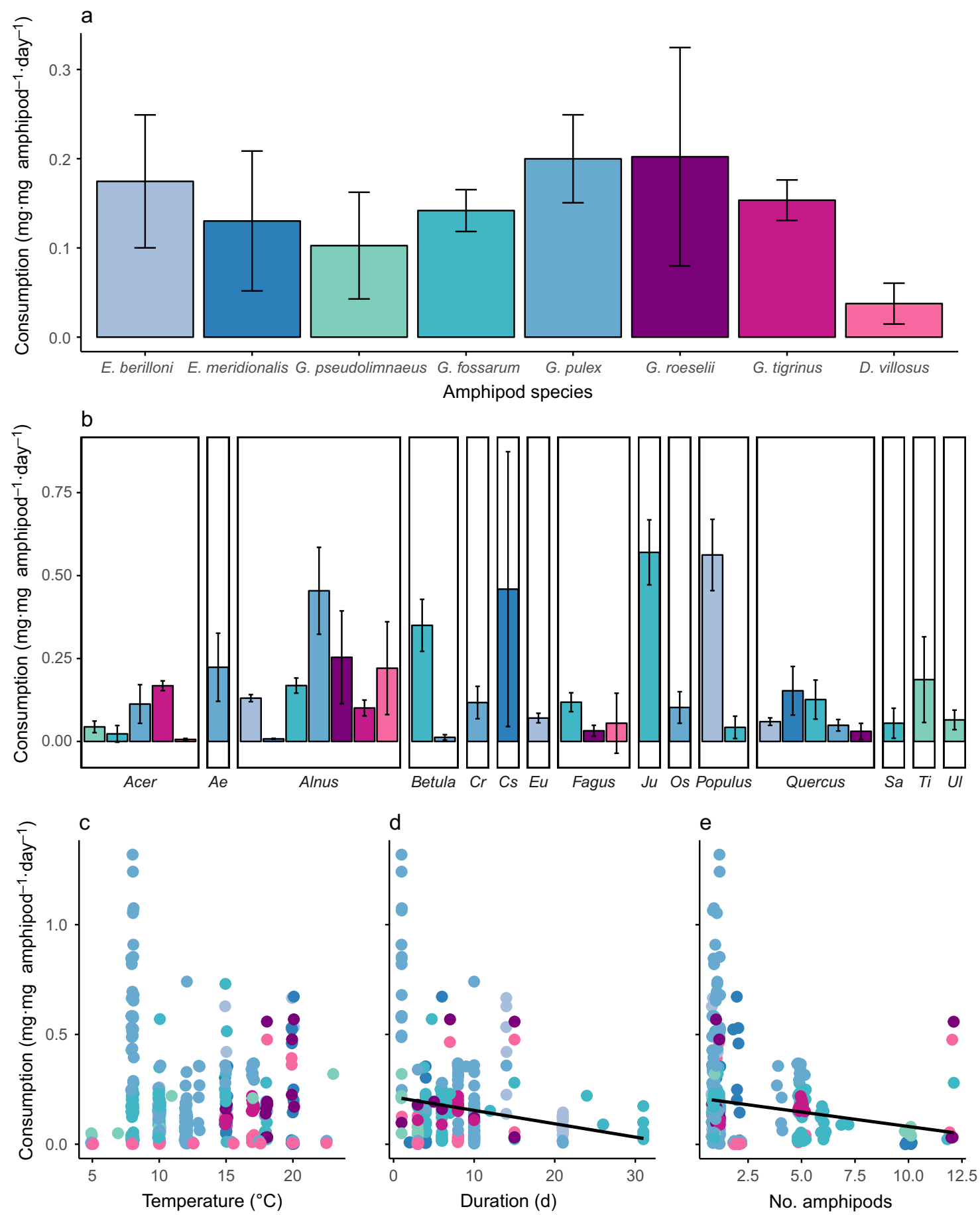

FIG. 6. Consumption rates of different leaf types by different amphipod species based on our meta-analysis of 48 studies with 303 group means. (a) Consumption rates varied with amphipod species between native Echinogammarus berilloni, E. meridionalis, G. pseudolimnaeus, G. fossarum, and G. pulex, and nonnative G. roeselii, G. tigrinus, and D. villosus, as well as (b) with leaf type. Leaf genus names are abbreviated where necessary: Ae, Aesculus; Cr, Carpinus; Cs, Castanea; Eu, Eucalyptus; Ju, Juglans; Os, Ostrya; Sa, Salix; Ti, Tilia; Ul, Ulmus. Experimental conditions such as (c) water temperature, (d) experimental duration, and (e) density of amphipods were other variables potentially explaining consumption rate; regression lines indicate which variables were included as important after model selection (regression lines are for illustrative purposes only). Error bars show 95\% confidence intervals from meta-analytical statistics; colors in panels b-d are as labeled in panel a.

To independently assess the effect of water contamination while holding other variables constant, we conducted a meta-analysis of the 19 studies comprising 125 data points where water quality was manipulated (Table 3 ). In our separate analysis of the effects of water contamination, we found a strong negative effect (overall $\log$ response ratio $=-0.26$; Fig. 7) of contamination on leaf consumption rate. For the log response ratio to water contamination 
TABLE 3. Studies included in the analysis of water contamination effects of leaf consumption by amphipods.

\begin{tabular}{|c|c|c|c|c|}
\hline Study & Amphipod species & Leaf type & Stressor & Location \\
\hline Bundschuh et al. (2013) & D. villosus, G. roeselii & Alnus glutinosa & pesticide & Germany \\
\hline Bundschuh et al. (2017) & G. fossarum & Alnus glutinosa & antibiotics & Germany \\
\hline Colas et al. (2016) & G. pulex & Alnus glutinosa & metals, polyaromatic hydrocarbons & France \\
\hline De Castro-Català et al. (2017) & G. pulex & Alnus glutinosa & fungicide, pharmaceutical & England \\
\hline Dedourge-Geffard et al. (2013) & G. fossarum & Alnus glutinosa & cadmium, zinc & France \\
\hline Dehedin et al. (2013a) & G. pulex, G. roeselii & Alnus glutinosa & ammonia & France \\
\hline Flores et al. (2014) & E. berilloni & Alnus glutinosa & fungicide, pesticide & Spain \\
\hline Macedo-Sousa et al. (2007) & E. meridionalis & Alnus glutinosa & acid mine drainage & Portugal \\
\hline Pesce et al. (2016) & G. fossarum & Alnus glutinosa & fungicide & France \\
\hline Pestana et al. (2007) & E. meridionalis & Castanea sativa & cadmium, zinc & Portugal \\
\hline Quintaneiro et al. (2015) & E. meridionalis & Alnus glutinosa & copper, zinc & Portugal \\
\hline Schlief and Mutz (2006) & G. pulex & Betula pendula & acid mine drainage & Germany \\
\hline Schmidlin et al. (2015a) & G. fossarum & Fagus sylvatica & copper & Switzerland \\
\hline Schmidlin et al. (2015b) & G. fossarum & Fagus sylvatica & copper & Switzerland \\
\hline Zubrod et al. (2010) & G. fossarum & Alnus glutinosa & fungicide & Germany \\
\hline Zubrod et al. (2015) & G. fossarum & Alnus glutinosa & copper & Germany \\
\hline Zubrod et al. (2017a) & G. fossarum & Alnus glutinosa & insecticide & Germany \\
\hline Zubrod et al. (2017b) & G. fossarum & Alnus glutinosa & wastewater & Germany \\
\hline
\end{tabular}

model selection showed that amphipod species, leaf type, and water temperature were included in the best-fitting model. There was one other model within two $\mathrm{AIC}_{\mathrm{c}}$ units, which did not include leaf type and carried $27.8 \%$ of the weight in the model set vs. $27.9 \%$ of the weight going to the best-fitting model. After model averaging, leaf type only had an importance of 0.46 , while the model-averaged importance of water temperature was 0.91 and amphipod species was 0.99 . Interestingly, the type of stressor (for example, metals vs. fungicides or pesticides) was not a factor determining the strength of response to stress, with model-averaged importance of only 0.09 . In the studies we assessed, G. fossarum had generally showed generally small reductions in leaf consumption rate in response to water contamination (Fig. 7a), while responses of E. meridionalis, $G$. roeselii, and $G$. pulex varied substantially between studies.

The 120 per-amphipod consumption rate data points gathered in the meta-analysis were measured on only six of the focal species (E. meridionalis, G. fossarum, G. pulex, $G$. roeselii, $D$. villosus, and $G$. tigrinus) with fewer measurements per species. Using these data, amphipod species, leaf genus, contamination of water, and length of experiment were included in the best-fitting model, which explained $57.42 \%$ of the heterogeneity in the data set. While the second-best model $(\triangle \mathrm{AIC}=1.96)$ also included amphipod density as a factor, multimodel inference showed that amphipod species (importance $=1.00$ ) and length of experiment (importance $=0.99$ ) were the most essential factors, while all others were less important (importance $<0.69$ ). Thus, across all 120 extracted data points, we only further examined the effects of amphipod species and study duration. Tested separately, each factor explained a significant $(P<0.0001)$ amount of variability. Leaf consumption varied by amphipod species (Fig. 8a), with highest per-individual consumption rates by the native $G$. fossarum and the lowest by the native E. meridionalis and nonnative G. tigrinus. However, data was even less evenly distributed in terms of leaf resource types than in the per-body-mass data set, with none of the G. tigrinus measurements, for example, being made on nitrogen-rich alder leaves, likely biasing results. Consumption rates also varied with experimental conditions; in particular experimental duration had a negative effect (Fig. 8b), however, a great bulk of the data came from very short-term experiments. As in the meta-analysis of body-weight adjusted consumption rates, not all experimental (or natural) conditions are equally well studied, also introducing bias.

\section{Discussion}

In our experiments, increasing the richness of decomposers and detritus often depressed leaf consumption rates. Both experiments and meta-analysis showed that nonnative amphipod species can have lower consumption rates than native species, as we had hypothesized. Combining the two approaches, we show that replacement of native shredders by nonnative species would result in lower leaf breakdown rates in streams but coexistence of native and nonnative species could partially mitigate these declines. The ecosystem-level effect of nonnative species replacing native species would also depend on a community's prior structure and the leaf consumption rate of the previously dominant species, and abiotic factors such as the presence of chemical stressors also has an important role in determining breakdown rates in changing ecosystems. Finally, the magnitude of any effect of nonnative amphipod species would depend on the types of detritus resources available in local ecosystems.

\section{Effects of leaf richness}

As expected, native G. fossarum consumed nitrogen-rich Alnus leaves more quickly than lower-nutrient leaf resources. But contrary to our hypothesis that more diverse leaf litter mixtures would be consumed more 


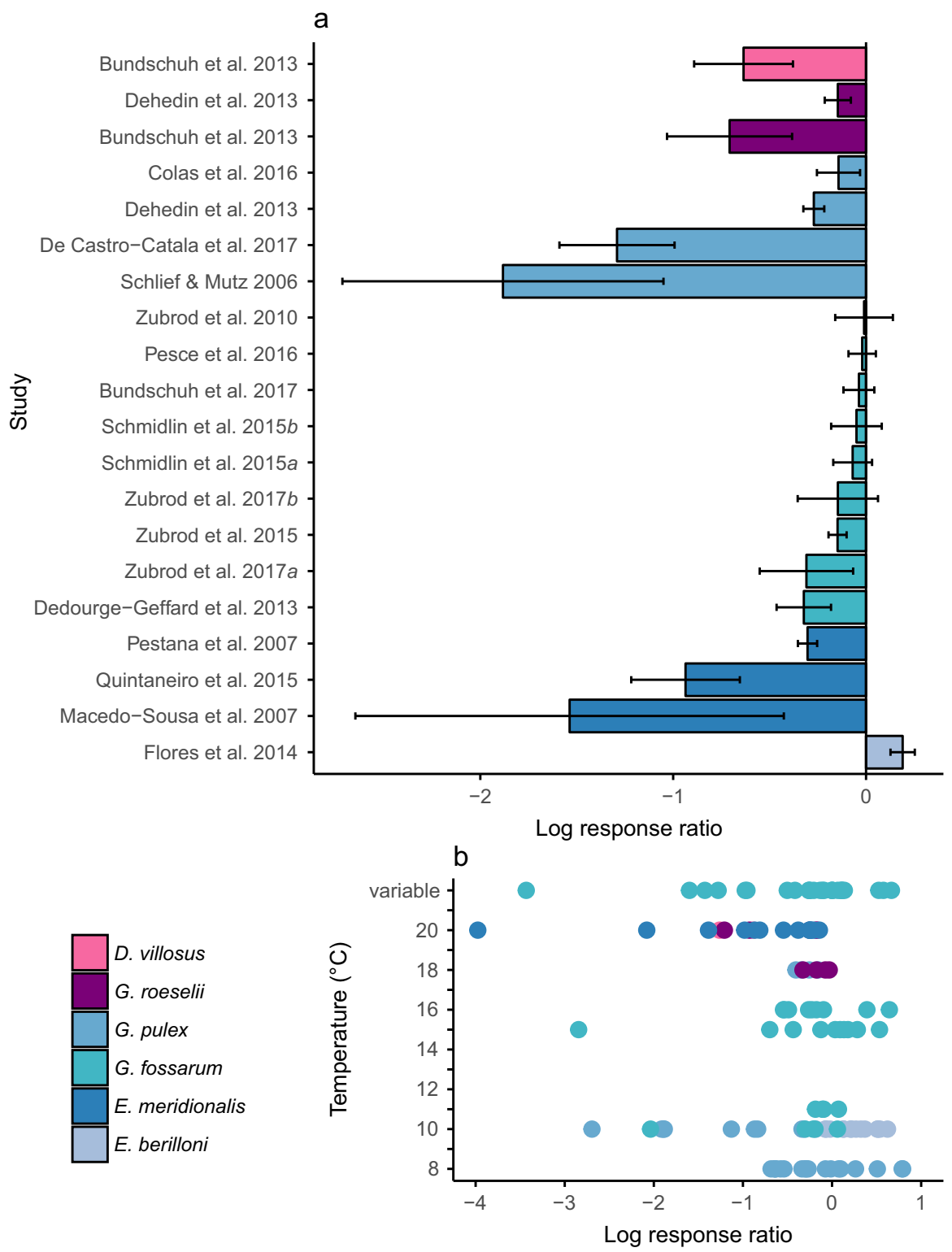

FIG. 7. (a) Log response ratio of leaf consumption by six common amphipod species in contaminated compared to natural water conditions in 14 studies in (b) different experimental water temperatures including variable temperatures in streams.

quickly, we found that increasing the species richness of litter offered to the most common Central European native amphipod species, G. fossarum, did not promote leaf consumption rates. In some cases, litter consumption rates were lower than would be predicted from relevant monocultures. However, we did find some indications of preferential feeding on nutrient-rich resources: in three of six mixtures, consumption rates of Alnus leaves were not significantly different than in Alnus monocultures, while consumption rates of other species were low. In these cases, amphipods chose the resources with the most nitrogen and phosphorus. In three other mixtures, however, consumption rates of both Alnus and the other leaf types were lower than in relevant monocultures. For the most species-rich mixture in particular, this resulted in extremely low, near-zero leaf consumption rates. This is contrasting some previous work with G. fossarum (Jabiol and Chauvet 2012), as well as some other aquatic and terrestrial work finding that litter diversity increased decomposition (Swan et al. 2009, Lecerf et al. 2011, Handa et al. 2014). Since consumption rates of leaf mixtures were more similar than consumption rates of the different monocultures, resource diversity may have the effect of homogenizing leaf decomposition and resource provisioning to freshwater ecosystems through time (Swan 2011). Most laboratory or field experiments assessing leaf breakdown rates, however, use leaf monocultures, often of Alnus, which has a particularly high consumption rate by macroinvertebrates due to its high nutrient content and rarely grows in monocultures, meaning that estimates of leaf consumption rates or even amphipod behavior when offered only this food source may lead to unrealistic conclusions. Fagus was also often 

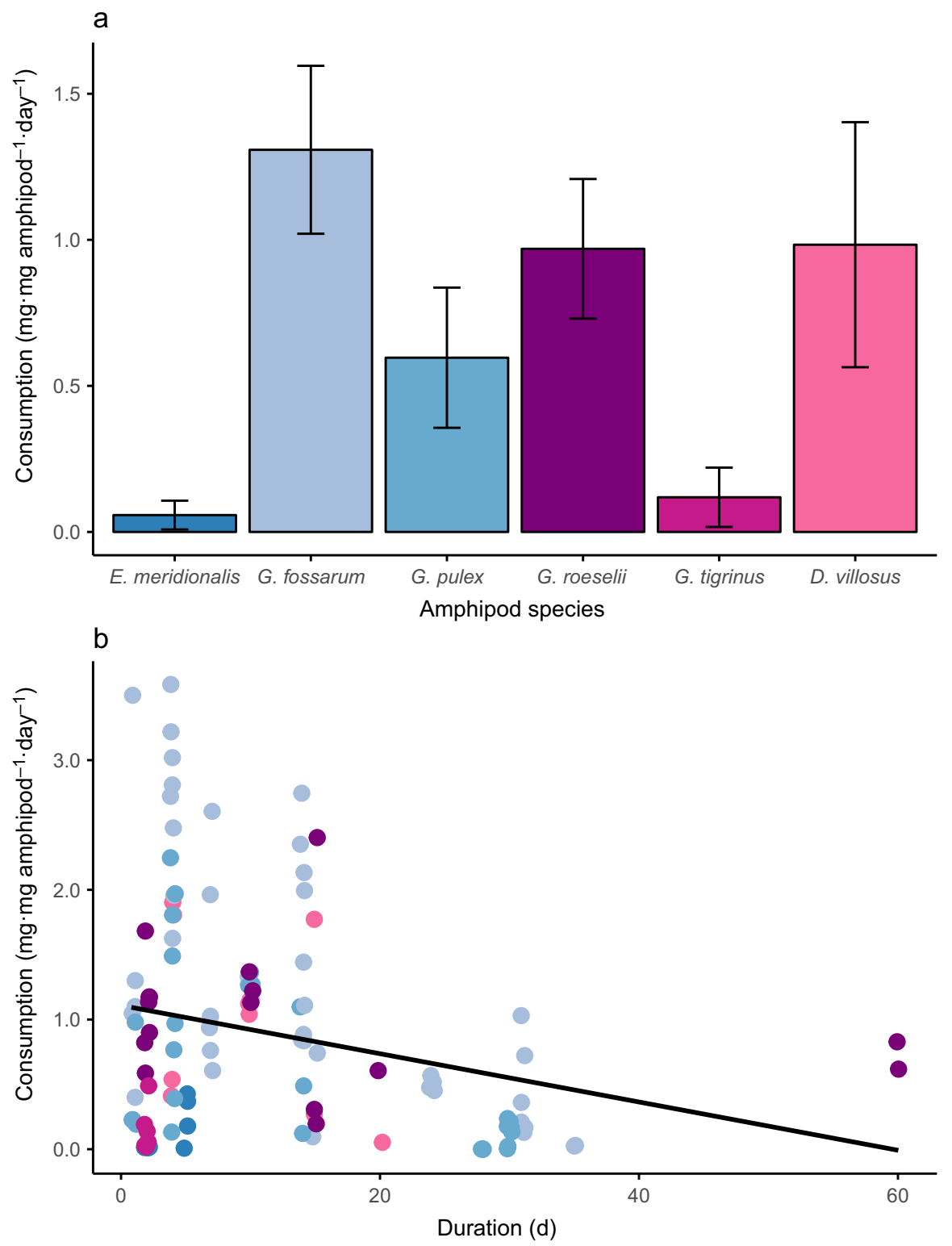

FIG. 8. Consumption rates of leaves by different amphipod species based on our meta-analysis of 101 group means. Consumption rates varied with (a) amphipod species and (b) experimental duration; error bars show $95 \%$ confidence intervals from meta-analytical statistics. Colors in panels $\mathrm{b}$ are as labeled in panel a.

commonly used in experiments, and this is much more realistic as many central European forests, including those in our study area, are beech dominated. Furthermore, our result provide further empirical support for the idea that for decomposition, species composition is more important than species richness (Kominoski and Pringle 2009, Bruder et al. 2014). Logistical constraints related to the number of mesocosms we could use prevented a factorial examination of the effects of litter diversity and amphipod species identity or richness on leaf consumption rates. However, the surprising decline in leaf consumption rates by G. fossarum in leaf mixtures, as has been found in isopods, smaller shredding invertebrates, where such a pattern was attributed to preferential feeding and interactions with microbial communities (Swan and Palmer 2006), suggests that such an experiment should be performed using nonnative species in order to obtain more accurate estimates of the effects of invaders on breakdown in realistic ecological settings.

\section{Effects of amphipod richness}

Increasing amphipod species richness in an experimental setting never led to comparable or higher leaf consumption rates as were found in the best-performing single-species mesocosms. In line with our hypothesis, increasing amphipod richness sometimes suppressed consumption rates of non-preferred resources (Quercus and Fagus) compared to weighted predictions made from relevant single-species measurements. This is particularly notable because as species richness increased in our substitutive design, intraspecific competition within each species should have decreased, and 
as found in the meta-analysis (Fig. 6e), lower densities of amphipods in monocultures have somewhat higher percapita leaf consumption rates. However, this release from intraspecific competition did not lead to an increase in leaf breakdown in the multi-species amphipod mixtures. Observed consumption rates of the preferred Alnus leaf resource never significantly differed from predictions. This was achieved partially through a selection effect: the observed consumption rates were more similar to that of the most-efficient species of the mix than to the mean predicted value. This is in line with other observations that selection effects can make consumer species identity in a community more important that species richness per se, especially in low-diversity systems, but that this effect can lead to either higher- or lower-than-predicted consumption rates $(\mathrm{McKie}$ et al. 2008, Godbold et al. 2009). Furthermore, regardless of resource quality, the difference in consumption between two species in monocultures was much greater than the difference between consumption by one species individually compared to a more diverse community.

Notably, our results suggest that the extent to which a community is invaded determines the strength of any effect on leaf breakdown rates. If a low-efficiency invader completely eliminates and replaces a native amphipod population, leaf breakdown may indeed be strongly depressed. However, if the same nonnative species arrives and instead coexists with a native community, particularly one made up of relatively lowefficiency native species such as G. fossarum (see also Dangles and Malmqvist 2004), effects on leaf breakdown may be minimal. Thus, the strength of a nonnative or even invasive species' effect on community structure is an important consideration when identifying risks to ecosystem function. In our experiment, leaf consumption rates were sometimes depressed in mesocosms where D. villosus was mixed with other amphipod species, but not to the same low level as in D. villosus monocultures. This true even when $D$. villosus had a negative effect on survival of others species.

A further consideration is total biomass of the community. We adjusted all of the leaf consumption rates measured in our experiments by the amount of amphipod biomass in each mesocosm. This serves to compare the leaf consumption efficiencies of communities of equal sizes. Yet if the arrival of a nonnative species changed not only community structure but also total shredder biomass, for instance in the replacement of $G$. duebeni celticus by the nonnative G. pulex in Ireland (Kelly and Dick 2005), then this will also have a large impact on leaf breakdown rates. Effects could then be predicted by combining information about the leaf consumption rates of different species with data on community size.

\section{Consumption rates by native and nonnative amphipods}

Our meta-analysis demonstrated that native amphipod species have a wide range of leaf consumption rates, from intermediate to high, meaning that litter breakdown may vary substantially between catchments with different locally dominant native species. Furthermore, species also showed different consumption rates across the range of leaf resources available, thus forest composition and the mixture of leaves shed into the aquatic ecosystems also determine catchment-level leaf breakdown rates. Meanwhile, leaf consumption rates were generally intermediate to low for nonnative amphipod species, indicating that, as we had hypothesized, replacement of native species by nonnative species has the strong potential to diminish litter breakdown as a key ecosystem process. No measurements of leaf consumption rate were found for nonnative species inside their native ranges, so it is unknown whether they have intrinsically lower trait values or whether they may consume familiar resources more quickly and efficiently.

Generally, our meta-analysis highlighted that current experiments are insufficient to predict the effects of nonnative species on breakdown in realistic biological contexts. For instance, no experiments working with nonnative amphipod species used temperatures lower than $15^{\circ} \mathrm{C}$, which could lead to mischaracterization of leaf consumption by Ponto-Caspian species that evolved in conditions typically warmer than in Central Europe and the Alps where they have invaded. Higher temperatures have the additional effect of increasing microbial decomposition and reducing the contribution of invertebrates to litter breakdown (Boyero et al. 2011). The meta-analysis showed variable effects of temperature on breakdown rates, and did not lend support to our hypothesis that higher temperatures would lead to higher leaf consumption due to metabolic demands; but this may have been due to the uneven distribution of experimental conditions between amphipod species, combined with the different thermal preferences of the species (Table 1). Also, no experiments in the metaanalysis measured consumption at temperatures below $8^{\circ} \mathrm{C}$, even though leaf litter availability is most pronounced in winter (after autumn leaf litter deposition). Furthermore, consumption rates by some amphipod species were only measured on a subset of possible leaf litter types, which may not even be the most common/available ones. This not only biases predictions, but prevents up-scaling/ forecasting of breakdown rates to the whole ecosystem level. We thus strongly recommend that future studies should emphasize using locally common leaves when measuring consumption rates, rather than solely focusing on the most common study materials, such as the unusually high-quality resource, nitrogen-rich Alnus.

Because of their low consumption rates, it is unlikely that more efficient use of allochthonous detritus is a major contributing factor to the successful invasions by nonnative amphipod species such as G. tigrinus or D. villosus. These species are placed firmly in the omnivore category, with D. villosus occupying trophic positions ranging from 1.9 to 2.6 (Hellmann et al. 2015). There is evidence that D. villosus feeding behavior in an invaded habitat changes over time (Van Riel et al. 2006) and differs among invaded rivers (Hellmann et al. 2015). Thus it is unclear to what extent detrital shredding efficiency structures gammarid communities, or what role it plays in invasion success. The establishment of amphipod invaders may be linked to life history traits, such as greater reproductive capacity (Pöckl 2009) or higher survival rates in degraded habitats (MacNeil et al. 2004), with differences in leaf consumption rates as a consequence rather than a cause of success.

Finally, our meta-analysis made clear that contamination from pesticides, herbicides, heavy metals, and mine drainage significantly decrease leaf breakdown rates regardless of 
native or nonnative dominance of a community. Our data set is not exhaustive in this respect; many more ecotoxicological studies have been performed using measurements like percent leaf loss, which, however, are not translatable into one common response unit that allows an across-study comparison. Thus, the magnitude of such declines in functioning may very well depend on species identity. However, it is clear that shredding rates by native amphipods are severely impacted by pollution (Thompson et al. 2016a). As a consequence, when the arrival of nonnative species accompanies stream degradation, the effect of these abiotic conditions on native species' functioning should be explicitly considered as a baseline. Changes in leaf breakdown rates resulting from shifting community structure can then be predicted, and finally the potential interactive effects of nonnative species and abiotic stressors should be examined (Didham et al. 2007).

\section{Conclusions}

Evidence from our own experiments and meta-analysis show that different native and nonnative species in an important freshwater shredder guild have different leaf consumption efficiencies and prefer different leaf resources. However, the leaf consumption traits of nonnative amphipod species are neither in line to facilitate their invasion success, nor to necessarily predict a crash in leaf breakdown and carbon provisioning in stream ecosystems after their establishment. This does not preclude such species from affecting ecosystem function in other ways, for instance indirectly by shifting biomass and community structure. Nevertheless, effects of nonnative species on ecosystem functioning should take into account biotic interactions such as competition and coexistence with similar native species, as well as what resources are realistically available and how efficiently potentially invasive species can exploit those resources.

\section{ACKNOWLeDGMents}

C. J. Little and F. Altermatt jointly developed the experimental design. C. J. Little performed the experiment; conceived the metaanalysis and analyzed all experimental and meta-analytical data; and wrote the initial draft of the manuscript. Both authors contributed to revisions. The authors thank Emanuel A. Fronhofer, Eric Harvey, Pravin Ganesanandamoorthy, Elvira Mächler, Chris Lindsay, Daniel Steiner, and Serge Robert for help with lab and field work, and Gregory Goldsmith, Brad Taylor, Eric Harvey, Roman Alther, and Elvira Mächler for helpful comments on the manuscript, as well as four anonymous reviewers. This project was funded by Swiss National Science Foundation grant PP00P3 150698 .

\section{Literature Cited}

Agatz, A., and C. D. Brown. 2014. Variability in feeding of Gammarus pulex: moving towards a more standardised feeding assay. Environmental Sciences Europe 26:15.

Alofs, K. M., and D. A. Jackson. 2014. Meta-analysis suggests biotic resistance in freshwater environments is driven by consumption rather than competition. Ecology 95:3259-3270.

Altermatt, F., R. Alther, C. Fišer, J. Jokela, M. Konec, D. Küry, E. Mächler, P. Stucki, and A. M. Westram. 2014. Diversity and distribution of freshwater amphipod species in Switzerland (Crustacea: Amphipoda). PLoS ONE 9:e110328.
Altermatt, F., R. Alther, and E. Mächler. 2016. Spatial patterns of genetic diversity, community composition and occurrence of native and non-native amphipods in naturally replicated tributary streams. BMC Ecology 16:23.

Aßmann, C., K. Rinke, J. Nechwatal, and E. von Elert. 2011. Consequences of the colonisation of leaves by fungi and oomycetes for leaf consumption by a gammarid shredder. Freshwater Biology $56: 839-852$.

Balvanera, P., A. B. Pfisterer, N. Buchmann, J.-S. He, T. Nakashizuka, D. Raffaelli, and B. Schmid. 2006. Quantifying the evidence for biodiversity effects on ecosystem functioning and services. Ecology Letters 9:1146-1156.

Banning, M. 1990. Der RheoIndex-eine möglichkeit zur berechnung der auswirkungen des flußstaus auf die benthische lebensgemeinschaft. Erweiterte Zusammenfassung der Jahrestagung der DGL, Essen, Germany.

Banning, M. 1998. Auswirkungen des aufstaus größerer flüsse auf das makrozoobenthos dargestellt am beispiel der Donau. Essener ökologische Schriften, Band 9, Westarp-Wiss enschaften, Hohenwarsleben, Germany.

Bärlocher, F. 1990. Factors that delay colonization of fresh alder leaves by aquatic hyphomycetes. Archiv für Hydrobiologie 119:249-255.

Beracko, P., A. Sýkorová, and A. Štangler. 2012. Life history, secondary production and population dynamics of Gammarus fossarum (Koch, 1836) in a constant temperature stream. Biologia 67:164-171.

Bird, G. A., and N. K. Kaushik. 1985. Processing of elm and maple leaf discs by collectors and shredders in laboratory feeding studies. Hydrobiologia 126:109-120.

Boeker, C., and J. Geist. 2015. Effects of invasive and indigenous amphipods on physico-chemical and microbial properties in freshwater substrates. Aquatic Ecology 49:467-480.

Boyero L., et al. 2011. A global experiment suggests climate warming will not accelerate litter decomposition in streams but might reduce carbon sequestration. Ecology Letters 14:289-294.

Brose, U., and H. Hillebrand. 2016. Biodiversity and ecosystem functioning in dynamic landscapes. Philosophical Transactions of the Royal Society B 371:20150267.

Bruder, A., M. H. Schindler, M. S. Moretti, and M. O. Gessner. 2014. Litter decomposition in a temperate and a tropical stream: the effects of species mixing, litter quality and shredders. Freshwater Biology 59:438-449.

Bundschuh, M., R. Gergs, S. Schadt, and R. Schulz. 2013. Do differences in sensitivity between native and invasive amphipods explain their coexistence in Lake Constance? A case study with lambda-cyhalothrin. Chemosphere 92:483-489.

Bundschuh, M., T. Hahn, M. O. Gessner, and R. Schulz. 2017. Antibiotic mixture effects on growth of the leaf-shredding stream detritivore Gammarus fossarum. Ecotoxicology 26:547554.

Bundschuh, M., J. P. Zubrod, S. Kosol, L. Maltby, C. Stang, L. Duester, and R. Schulz. 2011. Fungal composition on leaves explains pollutant-mediated indirect effects on amphipod feeding. Aquatic Toxicology 104:32-37.

Calcagno, V. 2013. glmulti: model selection and multimodel inference made easy. https://cran.r-project.org/web/packages/glmulti/ glmulti.pdf

Capps, K. A., and A. S. Flecker. 2015. High impact of low-trophicposition invaders: nonnative grazers alter the quality and quantity of basal food resources. Freshwater Science 34:784-796.

Cardinale, B. J., K. L. Matulich, D. U. Hooper, J. E. Byrnes, E. Duffy, L. Gamfeldt, P. Balvanera, M. I. O'Connor, and A. Gonzalez. 2011. The functional role of producer diversity in ecosystems. American Journal of Botany 98:572-592.

Colas, F., J. M. Baudoin, E. Chauvet, H. Clivot, M. Danger, F. A. Guérold, and S. Devin. 2016. Dam-associated multiple-stressor impacts on fungal biomass and richness reveal the initial signs of ecosystem functioning impairment. Ecological Indicators 60:1077-1090. 
Collins, S. M., T. J. Kohler, S. A. Thomas, W. W. Fetzer, and A. S. Flecker. 2016. The importance of terrestrial subsidies in stream food webs varies along a stream size gradient. Oikos 125: 674-685.

Constable, D., and N. J. Birkby. 2016. The impact of the invasive amphipod Dikerogammarus haemobaphes on leaf litter processing in UK rivers. Aquatic Ecology 50:1-9.

Coulaud, R., O. Geffard, B. Xuereb, E. Lacaze, H. Quéau, J. Garric, S. Charles, and A. Chaumot. 2011. In situ feeding assay with Gammarus fossarum (Crustacea): modelling the influence of confounding factors to improve water quality biomonitoring. Water Research 45:6417-6429.

Creed, R. P., R. P. Cherry, J. R. Pflaum, and C. J. Wood. 2009. Dominant species can produce a negative relationship between species diversity and ecosystem function. Oikos 118:723-732

Danger, M., J. Arce Funck, S. Devin, J. Heberle, and V. Felten. 2013. Phosphorus content in detritus controls life-history traits of a detritivore. Functional Ecology 27:807-815.

Dangles, O., and E. Chauvet. 2003. Effects of stream acidification on fungal biomass in decaying beech leaves and leaf palatability. Water Research 37:533-538.

Dangles, O., and B. Malmqvist. 2004. Species richness-decomposition relationships depend on species dominance. Ecology Letters 7:395-402.

De Castro-Català, N., I. Muñoz, J. L. Riera, and A. T. Ford. 2017. Evidence of low dose effects of the antidepressant fluoxetine and the fungicide prochloraz on the behavior of the keystone freshwater invertebrate Gammarus pulex. Environmental Pollution 231:406-414.

Dedourge-Geffard, O., L. Charron, C. Hofbauer, V. Gaillet, F. Palais, E. Lacaze, A. Geffard, and O. Geffard. 2013. Temporal patterns of digestive enzyme activities and feeding rate in gammarids (Gammarus fossarum) exposed to inland polluted waters. Ecotoxicology and Environmental Safety 97:139-146.

Dehedin, A., C. Maazouzi, S. Puijalon, P. Marmonier, and C. Piscart. 2013a. The combined effects of water level reduction and an increase in ammonia concentration on organic matter processing by key freshwater shredders in alluvial wetlands. Global Change Biology 19:763-774.

Dehedin, A., C. Piscart, and P. Marmonier. 2013b. Seasonal variations of the effect of temperature on lethal and sublethal toxicities of ammonia for three common freshwater shredders. Chemosphere 90:1016-1022.

Devin, S., C. Piscart, J. N. Beisel, and J. C. Moreteau. 2004. Life history traits of the invader Dikerogammarus villosus (Crustacea: Amphipoda) in the Moselle River, France. International Review of Hydrobiology 89:21-34.

Didham, R. K., J. M. Tylianakis, N. J. Gemmell, T. A. Rand, and R. M. Ewers. 2007. Interactive effects of habitat modification and species invasion on native species decline. Trends in Ecology and Evolution 22:489-496.

Dray, M. W., T. W. Crowther, S. M. Thomas, A. D. A'Bear, D. L. Godbold, S. J. Ormerod, S. E. Hartley, and T. H. Jones. 2014 Effects of elevated $\mathrm{CO}_{2}$ on litter chemistry and subsequent invertebrate detritivore feeding responses. PLoS ONE 9:1-7.

Dunoyer, L., L. Dijoux, L. Bollache, and C. Lagrue. 2014. Effects of crayfish on leaf litter breakdown and shredder prey: Are native and introduced species functionally redundant? Biological Invasions 16:1545-1555.

Eder, E., W. Hödl, O. Moog, H. Nesemann, M. Pöckl, and K. Wittmann. 1995. Crustacea. In O. Moog, editor. Fauna aquatica austriaca. Wasserwirtschaftskataster, Bundesministerium für Land- und Forstwirtschaft, Umwelt und Wasserwirtschaft, Vienna, Austria.

Ferreira, V., B. Castagneyrol, J. Koricheva, V. Gulis, E. Chauvet, and M. A. S. Graça. 2015. A meta-analysis of the effects of nutrient enrichment on litter decomposition in streams. Biological Reviews 90:669-688.
Ferreira, V., J. Koricheva, S. Duarte, D. K. Niyogi, and F. Guérold. 2016. Effects of anthropogenic heavy metal contamination on litter decomposition in streams - a meta-analysis. Environmental Pollution 210:261-270.

Flores, L., Z. Banjac, M. Farré, A. Larrañaga, E. Mas-Martí, I. Muñoz, D. Barceló, and A. Elosegi. 2014. Effects of a fungicide (imazalil) and an insecticide (diazinon) on stream fungi and invertebrates associated with litter breakdown. Science of the Total Environment 476-477:532-541.

Foucreau, N., C. Piscart, S. Puijalon, and F. Hervant. 2013a. Effect of climate-related change in vegetation on leaf litter consumption and energy storage by Gammarus pulex from continental or Mediterranean populations. PLoS ONE 8:e77242.

Foucreau, N., S. Puijalon, F. Hervant, and C. Piscart. 2013b. Effect of leaf litter characteristics on leaf conditioning and on consumption by Gammarus pulex. Freshwater Biology 58:1672-1681.

Foucreau, N., C. Piscart, S. Puijalon, and F. Hervant. 2016. Effects of rising temperature on a functional process: consumption and digestion of leaf litter by a freshwater shredder. Fundamental and Applied Limnology/Archiv für Hydrobiologie 187:295-306.

Franken, R. J. M., B. Waluto, E. T. H. M. Peeters, J. J. P. Gardeniers, J. A. J. Beijer, and M. Scheffer. 2005. Growth of shredders on leaf litter biofilms: the effect of light intensity. Freshwater Biology 50:459-466.

Friberg, N., and D. Jacobsen. 1994. Feeding plasticity of two detriviore-shredders. Freshwater Biology 32:133-142.

Früh, D., S. Stoll, and P. Haase. 2012. Physicochemical and morphological degradation of stream and river habitats increases invasion risk. Biological Invasions 14:2243-2253.

Galic, N., and V. E. Forbes. 2017. Effects of temperature on the performance of a freshwater amphipod. Hydrobiologia 785:35-46.

Gergs, R., and K. O. Rothhaupt. 2008. Feeding rates, assimilation efficiencies and growth of two amphipod species on biodeposited material from zebra mussels. Freshwater Biology 53:2494-2503.

Gessner, M. O., C. M. Swan, C. K. Dang, B. G. McKie, R. D. Bardgett, D. H. Wall, and S. Hättenschwiler. 2010. Diversity meets decomposition. Trends in Ecology and Evolution 25:372-380.

Godbold, J. A., M. Solan, and K. Killham. 2009. Consumer and resource diversity effects on marine macroalgal decomposition. Oikos 118:77-86.

Goedmakers, A. 1972. Gammarus fossarum Koch, 1835: redescription based on neotype material and notes on its local variation (Crustacea, Amphipoda). Bijdragen tot de Dierkunde 42:124 138.

Gonçalves, A. L., E. Chauvet, F. Bärlocher, M. A. S. Graça, and C. Canhoto. 2014. Top-down and bottom-up control of litter decomposers in streams. Freshwater Biology 59:2172-2182.

Haddaway, N. R., A. M. Collins, D. Coughlin, and S. Kirk. 2015. The role of Google Scholar in evidence reviews and its applicability to grey literature searching. PLoS ONE 10:1-17.

HandaI. T., et al. 2014. Consequences of biodiversity loss for litter decomposition across biomes. Nature 509:218-221.

Hättenschwiler, S., A. V. Tiunov, and S. Scheu. 2005. Biodiversity and litter decomposition in terrestrial ecosystems. Annual Review of Ecology, Evolution, and Systematics 36:191-218.

Hellmann, C., S. Worischka, E. Mehler, J. Becker, R. Gergs, and C. Winkelmann. 2015. The trophic function of Dikerogammarus villosus (Sowinsky, 1894) in invaded rivers: a case study in the Elbe and Rhine. Aquatic Invasions 10:385-397.

Hooper, D., et al. 2005. Effects of biodiversity on ecosystem functioning: a consensus of current knowledge. Ecology 75:3-35.

Hothorn, T., F. Bretz, and P. Westfall. 2008. Simultaneous inference in general parametric models. Biometrical Journal 50:346-363.

Jabiol, J., and E. Chauvet. 2012. Fungi are involved in the effects of litter mixtures on consumption by shredders. Freshwater Biology 57:1667-1677

Jourdan, J., B. Westerwald, A. Kiechle, W. Chen, B. Streit, S. Klaus, M. Oetken, and M. Plath. 2016. Pronounced species turnover, but no functional equivalence in leaf consumption of invasive amphipods in the river Rhine. Biological Invasions 18:763-774. 
Kelly, D. W., and J. T. A. Dick. 2005. Effects of environment and an introduced invertebrate species on the structure of benthic macroinvertebrate species at the catchment level. Archiv für Hydrobiologie 164:69-88.

Kenna, D., W. N. W. Fincham, A. M. Dunn, L. E. Brown, and C. Hassall. 2017. Antagonistic effects of biological invasion and environmental warming on detritus processing in freshwater ecosystems. Oecologia 183:875-886.

Kley, A., and G. Maier. 2006. Reproductive characteristics of invasive gammarids in the Rhine-Main-Danube catchment, South Germany. Limnologica 36:79-90.

Knapp, G., and J. Hartung. 2003. Improved tests for a random effects meta-regression with a single covariate. Statistics in Medicine 22:2693-2710.

Kominoski, J. S., and C. M. Pringle. 2009. Resource-consumer diversity: testing the effects of leaf litter species diversity on stream macroinvertebrate communities. Freshwater Biology 54:1461-1473.

Krauss, G., K. R. Sridhar, and F. Bärlocher. 2005. Aquatic hyphomycetes and leaf decomposition in contaminated groundwater wells in Central Germany. Archiv für Hydrobiologie 162:416-428.

Lagrue, C., J. S. Kominoski, M. Danger, J. M. Baudoin, S. Lamothe, D. Lambrigot, and A. Lecerf. 2011. Experimental shading alters leaf litter breakdown in streams of contrasting riparian canopy cover. Freshwater Biology 56:2059-2069.

Lecerf, A., G. Marie, J. S. Kominoski, C. J. Leroy, C. Bernadet, and C. M. Swan. 2011. Incubation time, functional litter diversity, and habitat characteristics predict litter-mixing effects on decomposition. Ecology 92:160-169.

Leuven, R. S. E. W., G. van der Velde, I. Baijens, J. Snijders, C. van der Zwart, H. J. R. Lenders, and A. bij de Vaate. 2009. The river Rhine: a global highway for dispersal of aquatic invasive species. Biological Invasions 11:1989-2008.

Little, C. J., and F. Altermatt. 2018. Do priority effects outweigh environmental filtering in a guild of dominant freshwater macroinvertebrates? Proceedings of the Royal Society B 285:1876.

Loreau, M., et al. 2001. Biodiversity and ecosystem functioning: current knowledge and future challenges. Science 294:804-808.

Maazouzi, C., C. Piscart, F. Legier, and F. Hervant. 2011. Ecophysiological responses to temperature of the "killer shrimp" Dikerogammarus villosus: Is the invader really stronger than the native Gammarus pulex? Comparative Biochemistry and Physiology Part A: Molecular and Integrative Physiology 159:268-274.

MacDougall, A. S., and R. Turkington. 2005. Are invasive species the drivers or passengers of change in degraded ecosystems? Ecology 86:42-55.

Macedo-Sousa, J. A., J. L. T. Pestana, A. Gerhardt, A. J. A. Nogueira, and A. M. V. M. Soares. 2007. Behavioural and feeding responses of Echinogammarus meridionalis (Crustacea, Amphipoda) to acid mine drainage. Chemosphere 67:1663-1670.

MacNeil, C., J. T. A. Dick, D. Platvoet, and M. Briffa. 2011. Direct and indirect effects of species displacements: an invading freshwater amphipod can disrupt leaf-litter processing and shredder efficiency. Journal of the North American Benthological Society 30:38-48.

MacNeil, C., and D. Platvoet. 2005. The predatory impact of the freshwater invader Dikerogammarus villosus on native Gammarus pulex (Crustacea: Amphipoda); influences of differentia microdistribution and food resources. Journal of Zoology 267:31.

MacNeil, C., J. Prenter, M. Briffa, N. J. Fielding, J. T. A. Dick, G. E. Riddell, M. J. Hatcher, and A. M. Dunn. 2004. The replacement of a native freshwater amphipod by an invader: roles for environmental degradation and intraguild predation. Canadian Journal of Fisheries and Aquatic Sciences 61:1627-1635.

Marchant, R., and H. B. N. Hynes. 1981. The distribution and production of Gammarus pseudolimnaeus (Crustacea: Amphipoda) along a reach of the Credit River, Ontario. Freshwater Biology $11: 169-182$

Mas-Martí, E., A. M. Romaní, and I. Muñoz. 2015. Consequences of warming and resource quality on the stoichiometry and nutrient cycling of a stream shredder. PLoS ONE 10:1-21.
McKie, B. G., G. Woodward, S. Hladyz, M. Nistorescu, E. Preda, C. Popescu, P. S. Giller, and B. Malmqvist. 2008. Ecosystem functioning in stream assemblages from different regions: contrasting responses to variation in detritivore richness, evenness and density. Journal of Animal Ecology 77:495-504.

Melbourne, B. A., et al. 2007. Invasion in a heterogeneous world: Resistance, coexistence or hostile takeover? Ecology Letters 10:77-94.

Mitchell, M. G. E., E. M. Bennett, and A. Gonzalez. 2013. Linking landscape connectivity and ecosystem service provision: current knowledge and research gaps. Ecosystems 16:894-908.

Navel, S., L. Simon, C. Lecuyer, F. Fourel, and F. MermillodBlondin. 2011. The shredding activity of gammarids facilitates the processing of organic matter by the subterranean amphipod Niphargus rhenorhodanensis. Freshwater Biology 56:481490.

Nery, T., and D. Schmera. 2015. The effects of top-down and bottom-up controls on macroinvertebrate assemblages in headwater streams. Hydrobiologia 763:173-181.

Nyman, A.-M., A. Hintermeister, K. Schirmer, and R. Ashauer. 2013. The insecticide imidacloprid causes mortality of the freshwater amphipod Gammarus pulex by interfering with feeding behavior. PLoS ONE 8:e62472.

Ortega, Y. K., and D. E. Pearson. 2005. Weak vs. strong invaders of natural plant communities: assessing invasibility and impact. Ecological Applications 15:651-661.

Paganelli, D., S. Caronni, A. Marchini, A. Gazzola, and R. Sconfietti. 2016. Dynamics and population structure of native Echinogammarus stammeri (Karaman, 1931) (Crustacea: Amphipoda) and non-native Gammarus roeselii Gervais, 1835 (Crustacea: Amphipoda) occurring in sympatry in Northern Italy. Italian Journal of Zoology 83:563-570.

Pesce, S., O. Zoghlami, C. Margoum, J. Artigas, A. Chaumot, and A. Foulquier. 2016. Combined effects of drought and the fungicide tebuconazole on aquatic leaf litter decomposition. Aquatic Toxicology 173:120-131.

Pestana, J. L. T., A. Ré, A. J. A. Nogueira, and A. M. V. M. Soares. 2007. Effects of cadmium and zinc on the feeding behaviour of two freshwater crustaceans: Atyaephyra desmarestii (Decapoda) and Echinogammarus meridionalis (Amphipoda). Chemosphere 68:1556-1562.

Petrin, Z., G. Englund, and B. Malmqvist. 2008. Contrasting effects of anthropogenic and natural acidity in streams: a meta-analysis. Proceedings of the Royal Society B 275:1143-1148.

Pinkster, S. 1973. The Echinogammarus berilloni-group, a number of predominantly Iberian amphipod species (Crustacea). Bijdragen tot de Dierkunde 43:1-38.

Piscart, C., R. Genoel, S. Doledec, E. Chauvet, and P. Marmonier. 2009. Effects of intense agricultural practices on heterotrophic processes in streams. Environmental Pollution 157:1011-1018.

Piscart, C., F. Mermillod-Blondin, C. Maazouzi, S. Merigoux, and P. Marmonier. 2011. Potential impact of invasive amphipods on leaf litter recycling in aquatic ecosystems. Biological Invasions 13:2861-2868.

Pöckl, M. 2007. Strategies of a successful new invader in European fresh waters: fecundity and reproductive potential of the PontoCaspian amphipod Dikerogammarus villosus in the Austrian Danube, compared with the indigenous Gammarus fossarum and G. roeseli. Freshwater Biology 52:50-63.

Pöckl, M. 2009. Success of the invasive Ponto-caspian amphipod Dikerogammarus villosus by life history traits and reproductive capacity. Biological Invasions 11:2021-2041.

Pöckl, M., and U. H. Humpesch. 1990. Intra- and inter-specific variations in egg survival and brood development time for Austrian populations of Gammarus fossarum and G. roeseli (Crustacea: Amphipoda). Freshwater Biology 23:441-455.

Pöckl, M., B. W. Webb, and D. W. Sutcliffe. 2003. Life history and reproductive capacity of Gammarus fossarum and G. roeseli (Crustacea: Amphipoda) under naturally fluctuating water temperatures: a simulation study. Freshwater Biology 48:53-66. 
Quintaneiro, C., J. Ranville, and A. J. A. Nogueira. 2015. Effects of the essential metals copper and zinc in two freshwater detritivores species: biochemical approach. Ecotoxicology and Environmental Safety 118:37-46.

R Core Team. 2016. R: a language and environment for statistical computing. R Foundation for Statistical Computing, Vienna, Austria. www.r-project.org

Reiss, J., R. A. Bailey, D. M. Perkins, A. Pluchinotta, and G. Woodward. 2011. Testing effects of consumer richness, evenness and body size on ecosystem functioning. Journal of Animal Ecology 80:1145-1154.

Ricciardi, A., and E. Bourget. (1998). Weight-to-weight conversion factors for marine benthic macroinvertebrates. Marine Ecology Progress Series, 163, 245-251.

Ricciardi, A., and H. J. MacIsaac. 2000. Recent mass invasion of the North American Great Lakes by Ponto-Caspian species. Trends in Ecology and Evolution 15:62-65.

Rigling A., and H. P. Schaffer, editors. 2015. Condition and use of Swiss forests. Federal Office for the Environment, Bern, Switzerland.

Sainte-Marie, B. 1991. A review of the reproductive bionomics of aquatic gammaridean amphipods: variation of life history traits with latitude, depth, salinity and superfamily. Hydrobiologia 223:189-227.

Santschi, F., I. Gounand, E. Harvey, and F. Altermatt. 2018. Leaf litter diversity and structure of microbial decomposer communities modulate litter decomposition in aquatic systems. Functional Ecology 32:522-532.

Schlief, J., and M. Mutz. 2006. Palatability of leaves conditioned in streams affected by mine drainage: a feeding experiment with Gammarus pulex (L.). Hydrobiologia 563:445-452.

Schmedtje, U., and M. Colling. 1996. Ökologische typisierung der aquatischen makrofauna. Informationsberichte des Bayerischen Landesamtes für Wasserwirtschaft, Munich, Germany.

Schmidlin, L., S. von Fumetti, and P. Nagel. 2015a. Effects of increased temperatures on Gammarus fossarum under the influence of copper sulphate. Ecotoxicology 24:433-444.

Schmidlin, L., S. von Fumetti, and P. Nagel. 2015b. Temperature effects on the feeding and electron transport system (ETS) activity of Gammarus fossarum. Aquatic Ecology 49:7180.

Schmidlin, L., S. von Fumetti, and P. Nagel. 2015c. Copper sulphate reduces the metabolic activity of Gammarus fossarum in laboratory and field experiments. Aquatic Toxicology 161:138145.

Schmidt-Kloiber, A., and D. Hering. 2015. www.freshwaterecology. info - An online tool that unifies, standardises and codifies more than 20,000 European freshwater organisms and their ecological preferences. Ecological Indicators 53:271-282.

Shea, K., and P. Chesson. 2002. Community ecology theory as a framework for biological invasions. Trends in Ecology \& Evolution 17:170-176.

Šidagyte, E., S. Solovjova, V. Šniaukštaite, A. Šiaulys, S. Olenin, and K. Arbačiauskas. 2017. The killer shrimp Dikerogammarus villosus (Crustacea, Amphipoda) invades Lithuanian waters, South-Eastern Baltic Sea. Oceanologia 59:85-91.

Sridhar, K. R., and F. Bärlocher. 1993. Seasonal changes in microbial colonization of fresh and dried leaves. Archiv für Hydrobiologie 128:1-12.

Sridhar, K. R., G. Krauss, F. Bärlocher, N. S. Raviraja, R. Wennrich, R. Baumbach, and G. J. Krauss. 2001. Decomposition of alder leaves in two heavy metal-polluted streams in central Germany. Aquatic Microbial Ecology 26:73-80.

Stachowicz, J. J., R. B. Whitlatch, and R. W. Osman. 1999. Species diversity and invasion resistance in a marine ecosystem. Science 286:1577-1579.

Strayer, D. L. 2010. Alien species in fresh waters: ecological effects, interactions with other stressors, and prospects for the future Freshwater Biology 55:152-174.
Sutcliffe, D. W., T. R. Carrick, and L. G. Willoughby. 1981. Effects of diet, body size, age and temperature on growth rates in the amphipod Gammarus pulex. Freshwater Biology $11: 183-214$.

Swan, C. M. 2011. Consumer presence and resource diversity independently induce stability of ecosystem function in a Piedmont stream. Ecosphere 2:art136.

Swan, C. M., M. A. Gluth, and C. L. Horne. 2009. Leaf litter species evenness influences nonadditive breakdown in a headwater stream. Ecology 90:1650-1658.

Swan, C. M., and M. A. Palmer. 2006. Preferential feeding by an aquatic consumer mediates non-additive decomposition of speciose leaf litter. Oecologia 149:107-114.

Tachet, H., P. Richoux, M. Bournaud, and P. Usseglio-Polatera. 2000. Invertébrés d'eau douce: systématique, biologie, écologie. CNRS editions, Paris, France.

Thébault, E., and M. Loreau. 2006. The relationship between biodiversity and ecosystem functioning in food webs. Ecological Research 21:17-25.

Thompson, M. S. A., et al. 2016a. Gene-to-ecosystem impacts of a catastrophic pesticide spill: testing a multilevel bioassessment approach in a river ecosystem. Freshwater Biology 61:2037-2050.

Thompson, P. L., B. Rayfield, and A. Gonzalez. 2016b. Loss of habitat and connectivity erodes species diversity, ecosystem functioning, and stability in metacommunity networks. Ecography 40:98-108.

Tilman, D., F. Isbell, and J. M. Cowles. 2014. Biodiversity and ecosystem functioning. Annual Review of Ecology, Evolution, and Systematics 45:471-493.

Truhlar, A. M., J. A. Dodd, and D. C. Aldridge. 2014. Differential leaf-litter processing by native (Gammarus pulex) and invasive (Dikerogammarus villosus) freshwater crustaceans under environmental extremes. Aquatic Conservation: Marine and Freshwater Ecosystems 24:56-65.

Väinölä, R., J. D. S. Witt, M. Grabowski, J. H. Bradbury, K. Jazdzewski, and B. Sket. 2007. Global diversity of amphipods (Amphipoda; Crustacea) in freshwater. Hydrobiologia 595:241-255.

Van den Brink, F. W. B., G. Van der Velde, and A. Bij de Vaate. 1991. Amphipod invasion on the Rhine. Nature 352:576.

Van Riel, M. C., G. Van Der Velde, S. Rajagopal, S. Marguillier, F. Dehairs, and A. Bij de Vaate. 2006. Trophic relationships in the Rhine food web during invasion and after establishment of the Ponto-Caspian invader Dikerogammarus villosus. Hydrobiologia 565:39-58.

Viechtbauer, W. 2010. Conducting meta-analyses in $\mathrm{R}$ with the metafor package. Journal of Statistical Software 36:1-48.

Wallace, J. B., S. L. Eggert, J. L. Meyer, and J. R. Webster. 1997. Multiple trophic levels of a forest stream linked to terrestrial litter inputs. Science 277:102-104.

Wallace, J. B., and J. R. Webster. 1996. The role of macroinvertebrates in stream ecosystem function. Annual Review of Entomology 41:115-139.

Waters, T. F., and J. C. Hokenstrom. 1980. Annual production and drift of the stream amphipod Gammarus pseudolimnaeus in Valley Creek, Minnesota. Limnology and Oceanography 25:700-710.

Webster, J. R., and E. F. Benfield. 1986. Vascular plant breakdown in freshwater ecosystems. Annual Review of Ecology and Systematics 17:567-594.

Woodward, G., and A. G. Hildrew. 2001. Invasion of a stream food web by a new top predator. Journal of Animal Ecology 70:273-288.

Woodward, G., G. Papantoniou, F. Edwards, and R. B. Lauridsen. 2008. Trophic trickles and cascades in a complex food web: impacts of a keystone predator on stream community structure and ecosystem process. Oikos 117:683-692.

Working group Aquatic Ecology (University Duisburg Essen). 2017. Dataset "Crustacea". www.freshwaterecology.info

Zubrod, J. P., M. Bundschuh, and R. Schulz. 2010. Effects of subchronic fungicide exposure on the energy processing of Gammarus fossarum (Crustacea; Amphipoda). Ecotoxicology and Environmental Safety 73:1674-1680. 
Zubrod, J. P., D. Englert, R. R. Rosenfeldt, J. Wolfram, S. Lüderwald, D. Wallace, N. Schnetzer, R. Schulz, and M. Bundschuh. 2015. The relative importance of diet-related and waterborne effects of copper for a leaf-shredding invertebrate. Environmental Pollution 205:16-22.

Zubrod, J. P., R. Bundschuh, D. Englert, M. Rohrberg, M. V. Wieczorek, N. Bakanov, R. Schulz, and M. Bundschuh. 2017a.
Transient effects following peak exposures towards pesticides - an explanation for the unresponsiveness of in situ measured functional variables. Environmental Pollution 231:1-5.

Zubrod, J. P., D. Englert, S. Lüderwald, S. Poganiuch, R. Schulz, and M. Bundschuh. 2017b. History matters: pre-exposure to wastewater enhances pesticide toxicity in invertebrates. Environmental Science and Technology 51:9280-9287.

\section{Data AcCessibility}

Data associated with this study are available from the Dryad Digital Repository: https://doi.org/10.5061/dryad.78g8h50 